\title{
International financial integration in the presence of an international duopoly
}

\section{Panagiotis Karavitis \& Michael S. Michael}

To cite this article: Panagiotis Karavitis \& Michael S. Michael (2022) International financial integration in the presence of an international duopoly, The European Journal of Finance, 28:8, 825-847, DOI: 10.1080/1351847X.2021.1931389

To link to this article: https://doi.org/10.1080/1351847X.2021.1931389

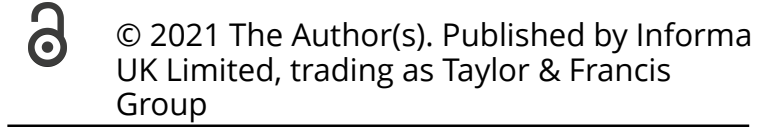
UK Limited, trading as Taylor \& Francis Group

曲 Published online: 24 May 2021.

Submit your article to this journal $\pi$

Џ Article views: 731

Q View related articles $\sqsubset$

View Crossmark data $\nearrow$ 


\title{
International financial integration in the presence of an international duopoly
}

\author{
Panagiotis Karavitis (1) and Michael S. Michael $\mathbb{1}^{\mathrm{b}}$ \\ ${ }^{a}$ Adam Smith Business School, University of Glasgow, Glasgow, UK; ${ }^{b}$ Department of Economics, University of Cyprus, Nicosia, \\ Cyprus
}

\begin{abstract}
We revisit the debate on the benefits of international financial integration. We build a partial equilibrium imperfectly competitive model with two countries, where each country has one firm. Firms are Cournot competitors. Within this framework, we examine how the liberalization of international capital flows affects the welfare of each country and their joint welfare. Our results show that international capital flows' liberalization cannot guarantee the improvement in each country's welfare and their joint welfare. Overall, we find that international financial integration has very heterogeneous effects, depending on the market size, the initial level of capital stock and the degree of product competition.
\end{abstract}

\section{ARTICLE HISTORY}

Received 28 May 2020

Accepted 12 May 2021

\section{KEYWORDS}

International financial integration; international capital flows liberalization; imperfect competition; partial equilibrium

\section{JEL CLASSIFICATIONS}

F12; F15; F21

\section{Introduction}

How does the international financial integration affect the welfare of the participant countries and their joint welfare? In the past few decades, we have witnessed a significant liberalization of international capital flows. According to international macroeconomic and financial theory, international financial integration leads to a more efficient allocation of capital and improves risk sharing across countries. Nevertheless, the welfare effects of the capital flows' liberalization can be characterized as rather controversial.

During the 1990s, the International Monetary Fund and most of the policymakers from developed countries supported financial account liberalization for developing economies as a vehicle for economic growth. A large number of countries have followed their advice. The beginning was prominent with a high volume of capital inflows and investments towards these countries associated with high growth rates. However, in turn, this capital flows' liberalization has generated significant global imbalances. A group of countries like Mexico, Russia, Argentina, Thailand, and South Korea with recently liberalized capital markets experienced severe financial crises that hurt these countries' welfare. ${ }^{1}$

The recent global financial crisis brings scepticism about international financial integration, even for the developed countries. During the eurozone crisis, for instance, some advanced economies that were entirely open to global capital flows were hit hard. Ireland, Spain, Greece, and Cyprus experienced deep recessions, while the last two countries were forced to impose strict restrictions on capital outflows. Olivier Blanchard, chief economist of the International Monetary Fund from 2008 until 2015, at the beginning of 2016 said, 'The general presumption was that capital account liberalization was always good and capital controls were nearly always bad. I've seen the thinking change. Partly because it was already wrong then, and because it was particularly wrong in the crisis. $^{2}$ 
In this paper, we re-examine how capital flows liberalization affects the welfare level of each participant country, and importantly, their joint welfare. We define financial integration as a reduction in the difference in the two countries' cost of capital. In addressing the welfare impact of international financial integration, we pose the following questions: Is the increase of international capital flows' liberalization, which causes convergence in the cost of capital, beneficial for the initially low and high capital cost countries? Does the increase in international financial integration lead to a higher joint welfare of the two countries?

To answer these questions, we build a two-country, partial equilibrium model of imperfect competition and examine the welfare implications of an increase in international financial integration level through the increase in international capital flows between the two participant countries. We use the international rivalry model of Brander and Krugman (1983), where each country, Home and Foreign, has one firm producing the same homogeneous good. The two firms are assumed to be Cournot competitors that consider each country as a separate market and therefore they choose the profit-maximizing quantity for each country separately. We assume capital abundance heterogeneity for the two countries, which implies different cost of capital for the two rival firms in autarky.

In this two-country framework, we analyze the following. First, we allow for a reduction in the unit cost of capital of the high-cost capital importing country and examine the effect on its welfare and on the two countries' joint welfare. Second, we allow for an increase in the unit cost of capital of the low-cost capital exporting country and examine the effect on its welfare and on the two countries' joint welfare. Third, in the simulation analysis, we allow for a simultaneous increase in the unit cost of capital for the low-cost capital exporting country and a reduction of the unit cost of capital of the high-cost capital importing country. Under this scenario, we examine the effect of these changes on each country's welfare and on their joint one. In this paper, we assume that the above changes in the unit cost of capital are due to the liberalization of international capital movements and the integration of the two countries' capital markets. Our analysis, however, is more general and these changes in the unit cost of capital could also be due to other reasons e.g. the reduction in the difference of the level of uncertainty between two countries.

Specifically, we run a marginal analysis to examine the welfare effects of a small change in the initial marginal cost of capital. This affects the welfare of each country by affecting the profits, consumer surplus and net capital payments (NCP). We show that an increase in international capital movements cannot guarantee improvements in each country's welfare or in the two countries' joint welfare. In particular, for the country with initially high capital cost, we find that even though the marginal cost of the local producer is reduced due to an increase of the international capital inflows, it needs a sufficiently large market size and/or a small difference in the initial cost of capital in order to be better off. Intuitively, under these conditions, the reduction in the cost of capital, causes larger increase in consumer surplus and profits and either a decrease or a small increase in the NCP. The low-cost country can be better off with an increase in international financial integration, but only if the difference in the initial costs of capital is small. In this case, the increase in NCP outweighs the decrease in profits and consumer surplus. Reducing the cost of capital in the country with high capital costs, increases the joint welfare when market is sufficiently large and/or the product market is close to perfect competition. Finally, increasing the cost of capital in the low-cost country unambiguously decreases the two countries' joint welfare. These results are robust to a series of sensitivity tests regarding the country size heterogeneity and the level of international financial integration.

In the simulation analysis, where we allow for a simultaneous convergence in the cost of capital between the two countries, we show among other things, the following. First, under a perfect financial integration, the joint welfare is higher if and only if the common cost of capital due to international capital flows is lower than the average cost of capital in the two countries under autarky (i.e. their initial cost of capital) and the total market size is sufficiently large. Intuitively, in this case, the liberalization of capital flows, which reduces the average cost of capital, reduces the average cost of production of the two rival firms. This reduces consumer prices, increases consumer surplus in both countries and increases total profits. Second, when the sum of the marginal costs of capital remains the same, then the case of a financially non-integrated capital market is welfare superior in terms of the two countries' joint welfare, compared to the case of a financially integrated one. This finding extends the work of Salant and Shaffer (1999), who show that when the marginal costs of the rival firms are linear, the asymmetric Cournot is welfare superior to the symmetric one. ${ }^{3}$ 
The relevant literature is highly fragmented and inconclusive. On the one hand, there are studies that find no correlation between capital account liberalization and growth (e.g. Alesina, Grilli, and Milesi-Ferretti 1994; Grilli and Milesi-Ferretti 1995; Kraay 1998; Rodrik 1998; Edison et al. 2002a). On the other hand, there are studies that find either a positive correlation (e.g. Quinn 1997; Quinn and Toyoda 2003) or studies that find negligible-mixed results (see e.g. Arteta, Eichengreen, and Wyplosz 2003; Edison et al. 2004; Bekaert, Harvey, and Lundblad 2005; Chanda 2005; Chinn and Ito 2005). Edwards (2001), Klein (2003), and Klein and Olivei (2008), provide evidence that international financial liberalization affects differently the low, middle, and high-income countries. These empirical studies provide estimations about the mean of their samples and thus it is difficult to generalize their findings (e.g. Henry 2007; Kose et al. 2009).

More recent studies, attempt to solve the puzzle regarding the impact of capital flows liberalization on a country's welfare. Gourinchas and Jeanne (2006), using a deterministic model find that financial integration leads to rather negligible welfare gains. Mendoza, Quadrini, and Rios-Rull (2009) find that international financial integration can lead to large and persistent global imbalances when countries differ in the degree of domestic financial development. De Nicolo and Juvenal (2014), using a sample from advanced and emerging market economies during 1985-2008, find that financial integration is associated with higher growth and financial stability. Colacito and Croce (2010) examine the welfare effect of financial integration in the short and long run, while (Corneli 2017), in a slightly different framework, examines the same issue for the financially developed and non-developed countries. In a concurrent study, Coeurdacier, Ray, and Winant (2019) examine the impact of financial integration on the growth of a country under uncertainty. They find that factors such as the country size, the initial level of capital abundance and the structure of the stochastic shocks affect the growth gains of a country.

Our paper contributes to the literature by providing some new findings as to why unrestricted international capital flows may not be beneficial for all countries involved. Contrary to previous studies that focus on how international financial integration affects a single country (e.g. Gourinchas and Jeanne 2006; Coeurdacier, Ray, and Winant 2019), our analysis identifies factors that affect not only each country's welfare but also their joint welfare. We show that such factors are the market size and the initial difference in the cost of capital between the two countries. Moreover, our simple model adds the degree of competition in the product market, a feature that has been ignored by the previous literature, as an important factor that determines the impact of international financial integration on welfare.

The paper is organized as follows. Section 2 develops the model. Section 3, using marginal analysis, examines the welfare effects of the convergence in the cost of capital due to increase in financial integration. In Section 4, we provide detailed simulation analysis using our theoretical model, and Section 5 gives the concluding remarks.

\section{The model}

Consider an asymmetric, two-country, cross-hauling model that is based on Brander and Krugman (1983). Each country, Home and Foreign, has one firm producing the same homogeneous good. The two firms are assumed to be Cournot competitors. In particular, each firm regards each country as a separate market and therefore chooses the profit-maximizing quantity for each country separately. The variables associated with Foreign are denoted by a starred letter. The relative variables for Home are denoted by unstarred letters.

The domestic (Foreign) firm produces output $x\left(x^{*}\right)$ for Home (Foreign) consumption and output $y\left(y^{*}\right)$ for Foreign (Home) consumption. Thus, $(x+y)$ represents the total Home production, while $\left(x^{*}+y^{*}\right)$ represents the total of Foreign's production. Countries are identical in size and have the same quasi-linear preferences that lead to the following linear inverse demands:

$$
\begin{aligned}
p(q) & =A-q ; \\
p^{*}\left(q^{*}\right) & =A-q^{*},
\end{aligned}
$$

where $A>0$ is the demand intercept that represents the market size, while $q=x+x^{*}$ and $q^{*}=y+y^{*}$ denote the total quantity in Home and Foreign, respectively. Note that with this set up $x$ and $x^{*}$, as well as $y$ and $y^{*}$, are perfect substitutes. ${ }^{4}$ Moreover, we consider capital as the only factor of production, and we assume full capital 
employment associated with constant returns to scale technology in both countries. We assume, for simplicity, that one unit of capital produces one unit of output. That is, $q(K)=K$. Thus,

$$
\begin{aligned}
c(R) & =R \times[x+y] ; \\
c\left(R^{*}\right) & =R^{*} \times\left[x^{*}+y^{*}\right],
\end{aligned}
$$

where Equations (3) and (4) are, respectively, the total production cost in Home and Foreign, while $R$ is the unit cost of capital in Home and $R^{*}$ the respective unit cost for Foreign. We assume that there is perfect competition in the capital market of each country. Thus, the price of a unit of capital equals the value of its marginal product. The value of the marginal product of capital is low (high) in the country with large (small) capital endowments. Without loss of generality, we assume that Home has small capital endowments and Foreign has relatively large capital endowments, which are exogenously given. ${ }^{5}$ As a result of these unequal capital endowments in the two countries, the cost of capital is higher in Home compared to Foreign (i.e. $\left.R>R^{*}\right)^{6}$

Given the assumption of quasi-linear preferences, we define our welfare measure as the sum of profits $\Pi$ and consumer surplus CS, minus or plus the net capital payments, $N C P($ i.e. $W=\Pi+C S \pm \phi N C P){ }^{7}$ The parameter $\phi$ takes the value 1 when international capital flows exist (i.e. $\phi=1$ ) or takes the value zero under autarky (i.e. $\phi=0) .{ }^{8}$ Because our analysis considers only the former case, in what follows $\phi=1$. That is,

$$
\begin{gathered}
W=\Pi+C S-N C P ; \\
W^{*}=\Pi^{*}+C S^{*}+N C P .
\end{gathered}
$$

Profits for each firm are equal to the revenue from sales in Home and Foreign minus the cost. That is,

$$
\begin{aligned}
\Pi & =p(q) x+p^{*}\left(q^{*}\right) y-R \times[x+y] ; \\
\Pi^{*} & =p(q) x^{*}+p^{*}\left(q^{*}\right) y^{*}-R^{*} \times\left[x^{*}+y^{*}\right] .
\end{aligned}
$$

The domestic and the Foreign firm maximize their profits as given by Equations (7) and (8) by choosing the optimal level of output for each market (see Appendix 1).

The consumer surplus, given the linear inverse demand functions (1) and (2), is given as:

$$
\begin{aligned}
C S & =\int_{0}^{q} p(u) \mathrm{d} u-p(q) q=\frac{q^{2}}{2} \\
C S^{*} & =\int_{0}^{q^{*}} p^{*}\left(u^{*}\right) \mathrm{d} u^{*}-p^{*}\left(q^{*}\right) q^{*}=\frac{q^{*^{2}}}{2} .
\end{aligned}
$$

When we allow for capital mobility between the two countries, Home becomes the capital importer country and thus Net Capital Payments are positive (i.e. $N C P>0$ ), while Foreign is the capital exporter country and thus receives net capital income. The net capital payments associated with the international capital flows, NCP, are the difference between country's production before capital mobility, which we denote as $\alpha=\left(\hat{x}^{0}+\hat{y}^{0}\right)$ and after capital mobility, times the price of one unit of capital. ${ }^{9}$ Using the first-order conditions (F.O.C.) for profit maximization (see Equation (A1)), the NCP can be written as ${ }^{10}$ :

$$
\begin{aligned}
N C P & =R^{T} \times\left[\left(\hat{x}^{T}+\hat{y}^{T}\right)_{c m}-\alpha\right]=R^{T} \times\left[\frac{2}{3}\left(A-2 R^{T}+R^{*}\right)-\alpha\right] \\
& =R^{T} \times\left[\frac{2}{3}\left(A-2 R^{T}+R^{*}\right)-\frac{2}{3}\left(A-2 R^{0}+R^{*}\right)\right] \\
& =R^{T} \times\left[\frac{4}{3}\left(R^{0}-R^{T}\right)\right],
\end{aligned}
$$

where $R^{T}$ denotes the domestic cost of capital after the capital mobility, $\left(\hat{x}^{T}+\hat{y}^{T}\right)$ represents the total domestic production after the capital mobility, and $R^{0}$ represents the domestic cost of capital before the capital mobility. 
In what follows, we use the simpler form of $N C P: N C P=R \times\left[(\hat{x}+\hat{y})_{c m}-\alpha\right]$, keeping in mind that the cost of capital $R$ represents the cost of capital after the capital mobility, $R^{T}$.

\section{Welfare effects of capital-market integration}

\subsection{Own welfare effects}

Our objective is to examine the effect on each country's welfare and on two countries' joint welfare when international financial integration increases under an imperfectly competitive product market. To this end, we run a one-shot game. At Stage 0, the two countries decide to increase international capital flows by lowering capital flows restrictions between them, and at Stage 1, the two firms choose non cooperatively their profit-maximizing quantities. Markets are segmented so that firms can treat each country as a separate market. We assume an interior equilibrium. That is, each firm produces a strictly positive output $\left((x+y)>0 ;\left(x^{*}+y^{*}\right)>0\right)$. This requires that the marginal costs $R$, and $R^{*}$ must satisfy the following condition: $R^{*}<R<A$. Substituting these outputs into Equations (5) and (6), we obtain the equilibrium welfare levels for the two countries.

First, we examine the case for Home. Substituting Equations (7), (9) and (11) into Equation (5) gives:

$$
\begin{aligned}
W & =\Pi+C S-N C P \\
& =\left(A-x-x^{*}\right) x+\left(A-y-y^{*}\right) y-R \times(x+y)+\frac{\left(x+x^{*}\right)^{2}}{2}-R \times(x+y-a) .
\end{aligned}
$$

Note that $x+y$ denotes the total production after the increase in international capital flows. ${ }^{11}$ Differentiating Equation (12) with respect to $R$, we obtain the following:

$$
\begin{aligned}
\frac{\partial W}{\partial R} & =(A-x-2 R) \frac{\partial x}{\partial R}+\left(A-2 y-y^{*}-2 R\right) \frac{\partial y}{\partial R}-y \frac{\partial y^{*}}{\partial R}+x^{*} \frac{\partial x^{*}}{\partial R}-2(x+y)-\alpha \\
& =\underbrace{-\frac{8}{9}\left(A-2 R+R^{*}\right)}_{(-)} \underbrace{-\frac{1}{9}\left(2 A-R-R^{*}\right)}_{(-)}-[\underbrace{\frac{2}{3}\left(A-2 R+R^{*}\right)-\alpha}_{(+)} \underbrace{\left.-\frac{4}{3} R\right]}_{(-)} .
\end{aligned}
$$

We obtain the results in the second line by using the expressions for the equilibrium outputs: $\hat{x}=\frac{1}{3}(A-$ $\left.2 R+R^{*}\right), \hat{y}=\frac{1}{3}\left(A-2 R+R^{*}\right), \hat{x}^{*}=\frac{1}{3}\left(A+R-2 R^{*}\right), \hat{y}^{*}=\frac{1}{3}\left(A+R-2 R^{*}\right)$ (see also Appendices 1 and 2$)$. Equation (13) shows how a change in the domestic cost of capital, $R$, affects each term of Home's welfare. In particular, given the restrictions for an interior solution (see Equation (A2)), a decrease in the cost of capital, $R$, increases both, the profits for the domestic firm (first term) and the consumer surplus (second term), but its effect on net capital payments is ambiguous. Doing some manipulations, Equation (13) can be written as: ${ }^{12}$

$$
W_{R}=-\frac{1}{9}\left(16 A-41 R+13 R^{*}-9 \alpha\right) \gtreqless 0 .
$$

As Equation (14) shows, the welfare effect of a reduction in the cost of capital for the high cost country is ambiguous. The likelihood that the reduction in $R$ improves Home's welfare increases if $A$ is very large and the difference $R-R^{*}$ is small. ${ }^{13}$ Intuitively, for given market size $A$, when $R$ is relatively low and close to $R^{*}$, it implies that the stock of capital in Home is large. This means, first that the production of Home's firm is relatively large and close to that of Foreign's firm. Thus, a reduction in $R$, which reduces the cost of production, has a larger positive effect on profits and consumer surplus for Home, compare to the case where Home's capital stock is small, $R$ is high and thus the difference $R-R^{*}$ is large. Second, a reduction in $R$ causes either a decrease or a small increase in NCP compare to the case when $R$ is high and thus $R-R^{*}$ is large where a decrease in $R$ causes an increase in NCP. For given cost of capital in the two countries, large market size, $A$, implies large consumer surplus and profits. Thus, the decrease in capital cost, $R$, which reduces the cost of production and prices, causes larger increase in consumer surplus and profits the higher the market size is. ${ }^{14}$ Therefore, a marginal cost reduction due to an increase in international capital flows is not always beneficial for the high capital cost country. 
Setting Equation (14) equal to zero and solving for the market size, we derive the required market size $A_{I}$ for Home to be indifferent between an increase in international capital flows or not

$$
W_{R}=0 \Rightarrow A_{I}=\frac{41 R-13 R^{*}+9 \alpha}{16} \Rightarrow A_{I}=\frac{13\left(R-R^{*}\right)+28 R+9 \alpha}{16} .
$$

Equation (14) shows that for a sufficiently large market size, say $A>A_{I}$, a reduction of $R$ due to an increase in international capital flows, increases Home's welfare, $W_{R}<0$. Intuitively, as we can see from Equation (14), in the case of a large-enough market size, $A>A_{I}$, Home's benefits from the reduction of $R$ due to higher profits, $\Pi_{R}=-\frac{8}{9}\left(A-2 R+R^{*}\right)<0$, and consumer surplus, $C S_{R}=-\frac{1}{9}\left(2 A-R-R^{*}\right)<0$, exceed NCP. Obviously, the inverse holds for a sufficiently small market size, $A<A_{I}$. The following proposition summarizes the previous results.

Proposition 3.1: Consider a two-country model with an international duopoly. An increase in international capital inflows, which decreases the cost of capital for the high-cost country, improves its welfare if the market size is sufficiently large and/or the difference in the cost of capital is sufficiently small.

Foreign has a large capital endowment compared to home, and thus its local firm buys capital at a lower cost (i.e. $R^{*}<R$ ). During the process of international financial integration, capital moves from the low return to the high-return country. Thus, Foreign becomes the capital exporter and its welfare is given by:

$$
\begin{aligned}
W^{*} & =\Pi^{*}+C S^{*}+N C P \\
& =\left(A-x-x^{*}\right) x^{*}+\left(A-y-y^{*}\right) y^{*}-R^{*} \times\left(x^{*}+y^{*}\right)+\frac{\left(y+y^{*}\right)^{2}}{2}-[-R \times(x+y-\alpha)],
\end{aligned}
$$

where the second line is derived using Equations (8) and (10). Differentiating Equation (16) with respect to $R^{*}$, gives:

$$
\begin{aligned}
& W_{R^{*}}^{*}=\frac{\partial W^{*}}{\partial R^{*}}=\left(A-2 x^{*}-x-R^{*}\right) \frac{\partial x^{*}}{\partial R^{*}}+\left(A-y^{*}-R^{*}\right) \frac{\partial y^{*}}{\partial R^{*}} \\
& -x^{*} \frac{\partial x}{\partial R^{*}}+y \frac{\partial y}{\partial R^{*}}-\left(x^{*}+y^{*}\right)+R\left(\frac{\partial x}{\partial R^{*}}+\frac{\partial y}{\partial R^{*}}\right) \\
& =\underbrace{-\frac{8}{9}\left(A+R-2 R^{*}\right)}_{(-)}-\underbrace{-\frac{1}{9}\left(2 A-R-R^{*}\right)+\frac{2}{3} R}_{(-)} .
\end{aligned}
$$

The second line is derived using the expressions for the equilibrium outputs: $\hat{x}=\frac{1}{3}\left(A-2 R+R^{*}\right), \hat{y}=\frac{1}{3}(A-$ $\left.2 R+R^{*}\right), \hat{x^{*}}=\frac{1}{3}\left(A+R-2 R^{*}\right), \hat{y}^{*}=\frac{1}{3}\left(A+R-2 R^{*}\right)$ (see also Appendix 1). Equation (17) denotes the effect of an increase in the cost of capital, $R^{*}$, on each component of Foreign's welfare. In particular, given the restrictions in Equation (A2), an increase in the cost of capital, $R^{*}$, unambiguously decreases the profits for the Foreign firm (first term), decreases the consumer surplus (second term), and increases the NCP (third term). Doing some manipulations, Equation (17) can be written as: ${ }^{15}$

$$
W_{R^{*}}^{*}=-\frac{1}{9}\left(10 A+R-17 R^{*}\right) \gtreqless 0 .
$$

Equation (18) shows that an increase in the cost of capital in Foreign has an ambiguous effect on its welfare. The likelihood that the increase in $R^{*}$ improves Foreign's welfare increases if market size, $A$, is small and the difference between $\mathrm{R}$ and $R^{*}$ is small given that $R^{*}<R$. Next, setting Equation (18) equal to zero and solving for the market 
size, we obtain the market size $A_{I}^{*}$, which makes Foreign indifferent between an increase in international capital flows or not.

$$
W_{R^{*}}^{*}=0 \Rightarrow 10 A+R-17 R^{*}=0 \Rightarrow A_{I}^{*}=\frac{-R+17 R^{*}}{10}
$$

The market size $A_{I}^{*}$ given by Equation (19) must be higher than $A^{\min }=2 R-R^{*}<A_{I}^{*}$, where $A^{\min }$ is the minimum market size we receive from the F.O.C. for an interior solution. In contrast with Home, for Foreign this condition is binding and requires two countries with similar costs of capital. That is:

$$
A^{\min }<A_{I}^{*} \Rightarrow 2 R-R^{*}<\frac{-R+17 R^{*}}{10} \Rightarrow \frac{R}{R^{*}}<\frac{27}{21} \Rightarrow R<\frac{27}{21} R^{*}
$$

The above analysis shows that an increase in $R^{*}$ due to capital mobility increases Foreign's welfare (i.e. $W_{R^{*}}^{*}>$ 0 ) if i) the two countries have similar capital costs (i.e. $R^{*}<R<\frac{27}{21} R^{*}$ ) in order for $A^{\text {min }}<A_{I}^{*}$ and ii) $A \in$ $\left(A^{\mathrm{min}}, A_{I}^{*}\right)$, which implies relatively small market size.

\section{Numerical examples}

We present below how an increase of Foreign's cost of capital, $R^{*}$, affects its welfare, using the restrictions of the F.O.C. for an interior solution (i.e. $A-2 R+R^{*}>0$ ) as well as Equations (18)-(20) for two different scenarios: (i) $A \in\left(A^{\mathrm{min}}, A_{I}^{*}\right)$ (i.e. a relatively small market size), and (ii) $A>A_{I}^{*}$ (i.e. a relatively large market size).

Example 3.1: The two countries have small differences in capital cost

Cost of capital for Home and Foreign: $\left(R=5, R^{*}=4\right) \Rightarrow \frac{R}{R^{*}}=(5 / 4)<\frac{27}{21}$.

So, using Equation (20): $A^{\min }<A_{I}^{*}$.

Using the F.O.C.: $A^{\mathrm{min}}=2 R-R^{*}>0 \Rightarrow A^{\mathrm{min}}=2(5)-4 \Rightarrow A^{\mathrm{min}}=6$.

Using Equation (18): $W_{R^{*}}^{*}>0 \Rightarrow A<\frac{-R+17 R^{*}}{10} \Rightarrow A<\frac{-5+17(4)}{10} \Rightarrow A<6.3$ and thus $A_{I}^{*}=6.3$.

So, for: $A \in\left(A^{\min }, A_{I}^{*}\right) \Rightarrow A \in(6,6.3), W_{R^{*}}^{*}>0$.

Using Equation (18):

Scenario 1: $A=6.1 \Rightarrow W_{R^{*}}^{*}=-\frac{1}{9}(10(6.1)+5-17(4))=-\frac{1}{9}(-2) \Rightarrow W_{R^{*}}^{*}=\frac{2}{9}>0$.

Scenario 2: $A=6.4 \Rightarrow W_{R^{*}}^{*}=-\frac{1}{9}(10(6.4)+5-17(4))=-\frac{1}{9}(1) \Rightarrow W_{R^{*}}^{*}=-\frac{1}{9}<0$.

Intuitively, in this case, the losses from the increase of $R^{*}$ in Foreign's profits $\left(\Pi_{R^{*}}^{*}=-\frac{8}{9}\left(A+R-2 R^{*}\right)<0\right)$ and consumer surplus: $\left(C S_{R^{*}}^{*}=-\frac{1}{9}\left(2 A-R-R^{*}\right)<0\right)$ do not exceed the revenue gains from NCP.

Example 3.2: The two countries have large differences in capital cost

Cost of capital for Home and Foreign: $\left(R=6, R^{*}=4\right) \Rightarrow \frac{R}{R^{*}}=(6 / 4)>\frac{27}{21}$.

So, using Equation (20): $A^{\min }>A_{I}^{*}$.

Using the F.O.C.: $A^{\mathrm{min}}=2 R-R^{*}>0 \Rightarrow A^{\mathrm{min}}=2(6)-4 \Rightarrow A^{\mathrm{min}}=8$.

Using Equation (18): $W_{R^{*}}^{*}>0 \Rightarrow A<\frac{-R+17 R^{*}}{10} \Rightarrow A<\frac{-6+17(4)}{10} \Rightarrow A<6.2$ and thus $A_{I}^{*}=6.2$.

So, for $\left(\boldsymbol{R}=6, \boldsymbol{R}^{*}=4\right): A^{\mathrm{min}}>A_{I}^{*}$, and thus there is no scenario that satisfies the condition for an interior solution and provides us $W_{R^{*}}^{*}>0 .{ }^{16}$ Proposition 3.2 summarizes this discussion.

Proposition 3.2: Consider a two-country model with an international duopoly. International capital mobility, which increases the cost of capital in the low-cost country, usually leads to deterioration of its welfare. Its welfare, however, improves if the differences in capital cost and market size are sufficiently small. 


\subsection{The two countries' joint welfare effects}

Next, we examine what happens to joint welfare when the cost of capital changes for the two countries. We define joint welfare as the sum of the two countries' welfare, as follows:

$$
J W=W+W^{*} .
$$

We begin by examining the effect of an increase in Home's cost of capital on the two countries' joint welfare, which is given as follows:

$$
\begin{aligned}
J W_{R}= & \underbrace{-\frac{8}{9}\left(A-2 R+R^{*}\right)}_{(-)} \underbrace{-\frac{1}{9}\left(2 A-R-R^{*}\right)}_{(-)} \\
& \underbrace{+\frac{4}{9}\left(A+R-2 R^{*}\right)}_{(+)} \underbrace{-\frac{1}{9}\left(2 A-R-R^{*}\right)}_{(-)} \\
= & -\frac{2}{9}\left(4 A-11 R+7 R^{*}\right)=-\frac{2}{9}\left(4 A-7\left(R-R^{*}\right)-4 R\right) \gtreqless 0 .
\end{aligned}
$$

NCP that clearly influences the results for each country's welfare, plays no role in the two countries' joint welfare, because they cancel each other. A reduction in $R$ due to capital inflow exerts a positive impact on Home's local monopolist profits (first term), a positive impact on Home's consumer surplus (second term), a negative impact on Foreign's local monopolist profits (third term), and a positive impact on Foreign's consumer surplus (fourth term). ${ }^{17}$ Surprisingly, under imperfect competition in the product market, the total effect from the reduction of $R$ is ambiguous. ${ }^{18}$ In our case, the ambiguity regarding the impact of international capital flows on welfare, is due to the existence of an imperfectly competitive product market. Note that under a perfectly competitive product market, the first and the third terms (i.e. the effect on the profits of the two rival monopolists) of Equation (22) are absent, and thus the total effect of the reduction in $\mathrm{R}$ on welfare is positive. If, however, the market size $A$ is sufficiently large and/or the difference between the initial costs of capital is small, then the decrease in $\mathrm{R}$ increases joint welfare. ${ }^{19}$

The above finding is a novel one and has vital policy implications. We show that under product market imperfection, international financial integration between the two countries can reduce their joint welfare. Therefore, the policymakers should consider the level of competition in the product market before deciding to liberalize their capital markets.

Next, we examine how an increase in Foreign's cost of capital, $R^{*}$, due to capital outflow affects joint welfare. Differentiating Equation (21) with respect to $R^{*}$ gives the effect on joint welfare as:

$$
J W_{R^{*}}=W_{R^{*}}^{*}+W_{R^{*}}=-\frac{2}{9}\left(4 A+7 R-11 R^{*}\right)<0 .
$$

Using the necessary condition for interior solution (i.e. $A>2 R-R^{*}$ ) and that $R>R^{*}$, we can show that $J W_{R^{*}}<0$. Thus, a marginal increase in $R^{*}$ has a negative impact on joint welfare (see Appendix 5 for analytical calculations).

The previous analysis has shown that an increase in $R^{*}$, i.e. the marginal cost of capital in the low cost Foreign, unambiguously decreases the joint welfare, while a decrease in $R$, the marginal cost of capital in the high cost Home has uncertain impact on joint welfare. To discuss the intuition for this asymmetric effect, we need to focus on the structure of the joint welfare function. According to Equation (21), joint welfare is the sum of consumer surpluses and profits in the two countries. When the two market sizes are the same, then consumer surpluses are the same in the two countries, but profits are larger in Foreign, the low capital cost country. Thus, when $R^{*}$, the marginal cost of capital in Foreign increases, it reduces the consumer surpluses in both countries as well as profits in Foreign, while it increases profits in Home. However, the reduction in Foreign's profits is larger than the increase in profits in Home, making the total effect of the increase in $R^{*}$ on joint welfare negative. 
When the marginal cost of the capital in Home, $R$, decreases, consumer surplus in both countries increase as well as profits in Home, while profits in Foreign decrease. Since profits in Foreign are larger than in Home, the decrease in Foreign profits is also larger than the increase in profits at Home. Thus, in this case, it is possible that the decrease in Foreign's profits outweighs the increase in Home's profits and consumer surpluses in both countries and thus the joint welfare to decrease.

Our analysis shows that only under certain conditions, the increase in international capital flows could increase the joint welfare of the countries involved. This result is a novel one and as far as we know, the impact of international financial integration on the joint welfare of a group of countries has not been examined before under product market imperfection. In the next proposition, we summarize the results of the above analysis:

Proposition 3.3: Within a two-country model of an international duopoly, we show that: (i) The reduction of the high cost of capital in Home may decrease joint welfare. It improves the joint welfare if the market size is sufficiently large and/or the difference between the initial costs of capital is small. (ii) The increase of the low capital cost in Foreign, $R^{*}$, unambiguously reduces the joint welfare.

Our previous marginal analysis shows that within an international duopoly model, the increase of international capital flows is far from a win-win situation for the two participant countries. We show that the welfare of Home, the country with high capital cost, improves for sufficiently large market size and/or small differences in the cost of capital. The welfare of Foreign, the low-cost country, increases with an increase in $R^{*}$ only under very restrictive assumptions and is very likely to decrease. Finally, we show that when $R$ is reduced, in order to get a Pareto-improved outcome for joint welfare, a large-enough market size, $A$, and/or a small difference between the initial costs of capital are needed. Our results depend on the model's assumption of imperfect competition, on the total market size, on the initial cost of capital in the two countries, and on the assumption of linearity in cost, preferences and the production technology.

The above outcome has important policy implications. First, it highlights that the effects of the financial integration on the two countries' joint welfare depends on the level of their product market competition. The likelihood that the capital market liberalization will increase the two countries' joint welfare, increases with the level of competition in their product market. Second, policymakers should pay attention on the total market size, as well as the similarity of capital markets in the two countries before proceeding with their capital market integration.

\subsection{Country size heterogeneity}

For simplicity, up to now, we assume no market-size heterogeneity for the two countries. In this section, we relax this assumption. We set Foreign's market size equal to $B$. Consequently, we redefine Foreign's inverse demand to capture the new Foreign market size as:

$$
p\left(q^{*}\right)=B-q^{*}
$$

where $B>0$ is the demand intercept that represents Foreign's market size. Utilizing Equations (1)-(8) but replacing the initial Foreign inverse demand (i.e. Equation (2) with Equation (24)), we run exactly the same analysis to the one of the Subsections 3.1-3.2.

The obtained results under market-size heterogeneity are consistent with our baseline results presented above. Specifically, the higher the total market size and the lower the difference between the initial cost of capital in the two countries, the easier it is for joint welfare to increase when Home's cost of capital falls. The results of Proposition 3.3 are not sensitive to country size heterogeneity (i.e. $A \gtrless B$ ). ${ }^{20}$ The latter holds because we have assumed that firms can sell their product in both countries without any trade or other cost. ${ }^{21}$

Because these results do not add more information than those obtained without market-size heterogeneity, and due to the complexity of the equations, we do not report them in the main text. Nevertheless, we provide a comprehensive table of simulations using the equations with market-size heterogeneity in Section 4 , which follows. 
Table 1. The welfare effects of international financial integration: similar market size $(A=B)$ and $|-d R|=\left|d R^{*}\right|$.

\begin{tabular}{|c|c|c|c|c|c|}
\hline $\begin{array}{l}\text { Level of international } \\
\text { financial integration }\end{array}$ & $\begin{array}{l}\text { Home's cost of } \\
\text { capital, } R\end{array}$ & $\begin{array}{l}\text { Foreign's cost } \\
\text { of capital, } R^{*}\end{array}$ & $\begin{array}{c}\text { Home } \\
\text { Welfare, } W\end{array}$ & $\begin{array}{c}\text { Foreign } \\
\text { Welfare, } W^{*}\end{array}$ & $\begin{array}{c}\text { Joint } \\
\text { Welfare, } J W \\
\end{array}$ \\
\hline \multicolumn{6}{|c|}{ Panel A: very small market size: $A=20 ; \alpha=2.67$} \\
\hline Level 0: No capital flows & 10 & 4 & 41.11 & 145.11 & 186.22 \\
\hline Level 1: Narrow financial integration & 9 & 5 & 30.44 & 135.78 & 166.22 \\
\hline Level 2: Deep financial integration & 8 & 6 & 27.78 & 126.44 & 154.22 \\
\hline Level 3: Perfect financial integration & 7 & 7 & 33.11 & 117.11 & 150.22 \\
\hline \multicolumn{6}{|c|}{ Panel B: small market size: $A=30 ; \alpha=9.33$} \\
\hline Level 0: No capital flows & 10 & 4 & 161.11 & 345.11 & 506.22 \\
\hline Level 1: Narrow financial integration & 9 & 5 & 163.78 & 322.44 & 486.22 \\
\hline Level 2: Deep financial integration & 8 & 6 & 174.44 & 299.78 & 474.22 \\
\hline Level 3: Perfect financial integration & 7 & 7 & 193.11 & 277.11 & 470.22 \\
\hline \multicolumn{6}{|c|}{ Panel C: moderate market size: $A=40 ; \alpha=16$} \\
\hline Level 0: No capital flows & 10 & 4 & 370.00 & 634.00 & 1004.00 \\
\hline Level 1: Narrow financial integration & 9 & 5 & 386.00 & 598.00 & 984.00 \\
\hline Level 2: Deep financial integration & 8 & 6 & 410.00 & 562.00 & 972.00 \\
\hline Level 3: Perfect financial integration & 7 & 7 & 442.00 & 526.00 & 968.00 \\
\hline \multicolumn{6}{|c|}{ Panel D: large market size: $A=60 ; \alpha=29.33$} \\
\hline Level 0: No capital flows & 10 & 4 & 1054.44 & 1478.44 & 2532.89 \\
\hline Level 1: Narrow financial integration & 9 & 5 & 1097.11 & 1415.78 & 2512.89 \\
\hline Level 2: Deep financial integration & 8 & 6 & 1147.78 & 1353.11 & 2500.89 \\
\hline Level 3: Perfect financial integration & 7 & 7 & 1206.44 & 1290.44 & 2496.89 \\
\hline \multicolumn{6}{|c|}{ Panel E: very large market size: $A=80 ; \alpha=42.67$} \\
\hline Level 0: No capital flows & 10 & 4 & 2094.44 & 2678.44 & 4772.89 \\
\hline Level 1: Narrow financial integration & 9 & 5 & 2163.78 & 2589.11 & 4752.89 \\
\hline Level 2: Deep financial integration & 8 & 6 & 2241.11 & 2499.78 & 4740.89 \\
\hline Level 3: Perfect financial integration & 7 & 7 & 2326.44 & 2410.44 & 4736.89 \\
\hline
\end{tabular}

\section{The welfare effects of the simulation analysis}

Section 3 covers the analysis of the marginal effects of a capital-cost convergence between two countries on their welfare levels and joint welfare. In this section, we run a simulation and examine how the convergence of the cost of capital due to international financial integration between the two countries affects (i) the welfare of the country with initially high capital cost, (ii) the welfare of the country with initially low capital cost, and (iii) the two countries' joint welfare. Specifically, we run a simulation using the model developed in Section 3, captured by Equations (1)-(8). ${ }^{22}$ The welfare levels of each country for the various levels of financial integration depend on the model parameters $\left\{R, R^{*}, A\right\}$. We set the initial, under autarky (i.e. without international capital flows), cost of capital for Home $R=10$ and for Foreign $R^{*}=4$. We consider four different market sizes: a very small market $(A=20)$, a small market $(A=30)$, a moderate market $(A=60)$, and a large market $(A=80) .{ }^{23}$ Note that according to the model's restrictions and our choices for $R$ and $R^{*}$, a market size $A>16$ is required for an interior solution.

In Tables 1-3, we show Home's, Foreign's, and their joint welfare for various levels of integration (no capital mobility, as well as small, medium, high, and perfect integration). The higher the level of international financial integration, the lower Home's cost of capital is (see Column 1 of each table), and the higher Foreign's cost of capital is (see Column 2). The last three columns show the welfare levels for Home, Foreign and their joint.

Table 1 presents the case where the change in Home's cost of capital equals the absolute value of the change in Foreign's cost of capital (i.e. $|-d R|=\left|d R^{*}\right|$ ). Under this scenario, the average cost of capital remains the same during the whole integration process (i.e. it is always identical to the initial one at Level 0 , and is equal to 7). We report three findings that are common across all the panels of Table 1. First, Home's welfare increases for a sufficiently large market size $A$, and/or a high level of financial integration. Second, Foreign's welfare decreases for each market size and each level of integration. Third, an increase in the capital-market integration always reduces the two countries' joint welfare. Across all the panels of Table 1, we can see that as the marginal costs of the two international rival firms come closer, the two countries' joint welfare decreases. Thus, we can conclude 
Table 2. The welfare effects of international financial integration: similar market size $(A=B)$ and $|-d R|>\left|d R^{*}\right|$.

\begin{tabular}{|c|c|c|c|c|c|}
\hline $\begin{array}{l}\text { Level of international } \\
\text { financial integration }\end{array}$ & $\begin{array}{l}\text { Home's cost of } \\
\text { capital, } R\end{array}$ & $\begin{array}{l}\text { Foreign's cost } \\
\text { of capital, } R^{*}\end{array}$ & $\begin{array}{c}\text { Home } \\
\text { Welfare, } W\end{array}$ & $\begin{array}{c}\text { Foreign } \\
\text { Welfare, } W^{*}\end{array}$ & $\begin{array}{c}\text { Joint } \\
\text { Welfare, JW }\end{array}$ \\
\hline \multicolumn{6}{|c|}{ Panel A: very small market size: $A=20 ; \alpha=2.67$} \\
\hline Level 0: No capital flows & 10.00 & 4.00 & 41.11 & 145.11 & 186.22 \\
\hline Level 1: Narrow financial integration & 9.00 & 4.50 & 33.40 & 142.90 & 176.31 \\
\hline Level 2: Moderate financial integration & 8.00 & 5.00 & 31.83 & 139.17 & 171.00 \\
\hline Level 3: Deep financial integration & 7.00 & 5.50 & 36.40 & 133.90 & 170.31 \\
\hline Level 4: Perfect financial integration & 6.00 & 6.00 & 47.11 & 127.11 & 174.22 \\
\hline \multicolumn{6}{|c|}{ Panel B: small market size: $A=30 ; \alpha=9.33$} \\
\hline Level 0: No capital flows & 10.00 & 4.00 & 161.11 & 345.11 & 506.22 \\
\hline Level 1: Narrow financial integration & 9.00 & 4.50 & 165.63 & 335.13 & 500.75 \\
\hline Level 2: Moderate financial integration & 8.00 & 5.00 & 176.28 & 323.61 & 499.89 \\
\hline Level 3: Deep financial integration & 7.00 & 5.50 & 193.07 & 310.57 & 503.64 \\
\hline Level 4: Perfect financial integration & 6.00 & 6.00 & 216.00 & 296.00 & 512.00 \\
\hline \multicolumn{6}{|c|}{ Panel C: moderate market size: $A=40 ; \alpha=16$} \\
\hline Level 0: No capital flows & 10.00 & 4.00 & 370.00 & 634.00 & 1004.00 \\
\hline Level 1: Narrow financial integration & 9.00 & 4.50 & 386.74 & 616.24 & 1002.97 \\
\hline Level 2: Moderate financial integration & 8.00 & 5.00 & 409.61 & 596.94 & 1006.56 \\
\hline Level 3: Deep financial integration & 7.00 & 5.50 & 438.63 & 576.13 & 1014.75 \\
\hline Level 4: Perfect financial integration & 6.00 & 6.00 & 473.78 & 553.78 & 1027.56 \\
\hline \multicolumn{6}{|c|}{ Panel D: large market size: $A=60 ; \alpha=29.33$} \\
\hline Level 0: No capital flows & 10.00 & 4.00 & 1054.44 & 1478.44 & 2532.89 \\
\hline Level 1: Narrow financial integration & 9.00 & 4.50 & 1095.63 & 1445.13 & 2540.75 \\
\hline Level 2: Moderate financial integration & 8.00 & 5.00 & 1142.94 & 1410.28 & 2553.22 \\
\hline Level 3: Deep financial integration & 7.00 & 5.50 & 1196.40 & 1373.90 & 2570.31 \\
\hline Level 4: Perfect financial integration & 6.00 & 6.00 & 1256.00 & 1336.00 & 2592.00 \\
\hline \multicolumn{6}{|c|}{ Panel E: very large market size: $A=80 ; \alpha=42.67$} \\
\hline Level 0: No capital flows & 10.00 & 4.00 & 2094.44 & 2678.44 & 4772.89 \\
\hline Level 1: Narrow financial integration & 9.00 & 4.50 & 2160.07 & 2629.57 & 4789.64 \\
\hline Level 2: Moderate financial integration & 8.00 & 5.00 & 2231.83 & 2579.17 & 4811.00 \\
\hline Level 3: Deep financial integration & 7.00 & 5.50 & 2309.74 & 2527.24 & 4836.97 \\
\hline Level 4: Perfect financial integration & 6.00 & 6.00 & 2393.78 & 2473.78 & 4867.56 \\
\hline
\end{tabular}

that within our model, the international financial integration, which equalizes the cost of capital in the two countries (i.e. level 3), causes their joint welfare to decrease, compared to the case of no international capital flows (i.e. level 0). That is, from the perspective of joint welfare, the case with asymmetric marginal cost of capital is welfare superior to the one with symmetric capital cost. This important result shows that the finding of Salant and Shaffer (1999), who show the welfare superiority of the asymmetric case, for a specific industry of a country, carries over to our case with an international duopoly, and international capital mobility.

Proposition 4.1: Assume two countries, one with high capital cost and one with low capital cost. International financial integration equalizes the cost of capital between the two countries. If the cost of capital under free international capital flows, $R^{\mathrm{cm}}$, is identical to the initial average cost of capital without international capital flows, $\left(R+R^{*}\right) / 2$, then this financial-integration process results in:

- an increase in Home's welfare for a sufficiently large market size and/or high level of integration,

- a decrease in Foreign's welfare,

- a decrease in the two countries' joint welfare (i.e. the asymmetric international duopoly is welfare superior to the symmetric one).

Keeping the assumption that the absolute change in Home's cost of capital equals the absolute change in Foreign's cost of capital (i.e. $|-d R|=\left|d R^{*}\right|$ ), we evaluate the robustness of Proposition 4.1 in the case of marketsize heterogeneity. We simulate the model in Equations (1)-(8), where the initial Foreign inverse demand defined in Equation (2) is replaced by (24). In Appendix 2, Table A4 reports the results when $A \leq B$ and Table A5 when 
Table 3. The welfare effects of international financial integration: Similar market size $(A=B)$ and $|-d R|<\left|d R^{*}\right|$.

\begin{tabular}{|c|c|c|c|c|c|}
\hline $\begin{array}{l}\text { Level of international } \\
\text { financial integration }\end{array}$ & $\begin{array}{l}\text { Home's cost of } \\
\text { capital, } R\end{array}$ & $\begin{array}{l}\text { Foreign's cost } \\
\text { of capital, } R^{*}\end{array}$ & $\begin{array}{c}\text { Home } \\
\text { Welfare, } W\end{array}$ & $\begin{array}{c}\text { Foreign } \\
\text { Welfare, } W^{*}\end{array}$ & $\begin{array}{c}\text { Joint } \\
\text { Welfare, JW } \\
\end{array}$ \\
\hline \multicolumn{6}{|c|}{ Panel A: very small market size: $A=20 ; \alpha=2.67$} \\
\hline Level 0: No capital flows & 10.00 & 4.00 & 41.11 & 145.11 & 186.22 \\
\hline Level 1: Narrow financial integration & 9.50 & 5.00 & 31.46 & 133.29 & 164.75 \\
\hline Level 2: Moderate financial integration & 9.00 & 6.00 & 24.94 & 122.94 & 147.89 \\
\hline Level 3: Deep financial integration & 8.50 & 7.00 & 21.57 & 114.07 & 135.64 \\
\hline Level 4: Perfect financial integration & 8.00 & 8.00 & 21.33 & 106.67 & 128.00 \\
\hline \multicolumn{6}{|l|}{ Panel B: small market size: $A=30 ; \alpha=9.33$} \\
\hline Level 0: No capital flows & 10.00 & 4.00 & 161.11 & 345.11 & 506.22 \\
\hline Level 1: Narrow financial integration & 9.50 & 5.00 & 159.24 & 321.07 & 480.31 \\
\hline Level 2: Moderate financial integration & 9.00 & 6.00 & 160.50 & 298.50 & 459.00 \\
\hline Level 3: Deep financial integration & 8.50 & 7.00 & 164.90 & 277.40 & 442.31 \\
\hline Level 4: Perfect financial integration & 8.00 & 8.00 & 172.44 & 257.78 & 430.22 \\
\hline \multicolumn{6}{|c|}{ Panel C: moderate market size: $A=40 ; \alpha=16$} \\
\hline Level 0: No capital flows & 10.00 & 4.00 & 370.00 & 634.00 & 1004.00 \\
\hline Level 1: Narrow financial integration & 9.50 & 5.00 & 375.90 & 597.74 & 973.64 \\
\hline Level 2: Moderate financial integration & 9.00 & 6.00 & 384.94 & 562.94 & 947.89 \\
\hline Level 3: Deep financial integration & 8.50 & 7.00 & 397.13 & 529.63 & 926.75 \\
\hline Level 4: Perfect financial integration & 8.00 & 8.00 & 412.44 & 497.78 & 910.22 \\
\hline \multicolumn{6}{|c|}{ Panel D: large market size: $A=60 ; \alpha=29.33$} \\
\hline Level 0: No capital flows & 10.00 & 4.00 & 1054.44 & 1478.4 & 2532.89 \\
\hline Level 1: Narrow financial integration & 9.50 & 5.00 & 1075.90 & 1417.74 & 2493.64 \\
\hline Level 2: Moderate financial integration & 9.00 & 6.00 & 1100.50 & 1358.50 & 2459.00 \\
\hline Level 3: Deep financial integration & 8.50 & 7.00 & 1128.24 & 1300.74 & 2428.97 \\
\hline Level 4: Perfect financial integration & 8.00 & 8.00 & 1159.11 & 1244.44 & 2403.56 \\
\hline \multicolumn{6}{|c|}{ Panel E: very large market size: $A=80 ; \alpha=42.67$} \\
\hline Level 0: No capital flows & 10.00 & 4.00 & 2094.44 & 2678.44 & 4772.89 \\
\hline Level 1: Narrow financial integration & 9.50 & 5.00 & 2131.46 & 2593.29 & 4724.75 \\
\hline Level 2: Moderate financial integration & 9.00 & 6.00 & 2171.61 & 2509.61 & 4681.22 \\
\hline Level 3: Deep financial integration & 8.50 & 7.00 & 2214.90 & 2427.40 & 4642.31 \\
\hline Level 4: Perfect financial integration & 8.00 & 8.00 & 2261.33 & 2346.67 & 4608.00 \\
\hline
\end{tabular}

$A \geq B$. Both scenarios yield qualitatively similar results to the ones in Table 1: (i) Home's welfare increases for a large-enough market size $(A+B)$ and/or high level of financial integration, (ii) Foreign's welfare decreases, and (iii) the joint welfare decreases as the financial integration proceeds.

We obtain the results in Table 1 under the assumption that $|-d R|=\left|d R^{*}\right|$. This condition yields an equilibrium, where the cost of capital under a perfectly integrated financial market equals the average cost of capital in the two countries without international capital flows (i.e. at Level 0). Table 2 and Figure 1 present the results under the assumption $|-d R|>\left|d R^{*}\right|$. In this case, the integration process ends up with a lower average cost than the one with no integration (i.e. 6 at Level 4 compared to 7 at Level 0).

Panel A in Table 2 presents the welfare levels for each level of financial integration between two relatively small countries $(A=20)$ and shows that Home must reach the highest level of integration (i.e. perfect financial integration) in order to enjoy a higher welfare level (47.11 at Level 4 compared to 41.11 at Level 0). Foreign is worse off, but the same holds for their joint welfare. In panel B we run the same exercise for a larger market size, $(A=30)$. In this case Home achieves a higher welfare level even from the first level of integration (165.63 at Level 1 compared to 161.11 at Level 0 ), while Foreign is again worse off. Joint welfare improves only under a perfectly integrated financial market (512 at Level 4 compared to 506.22 at Level 0 ). This means that we end up with a Pareto-improved outcome because Home's gains are high enough to fully compensate Foreign for its losses. As we mentioned before (see Section 3.2 and proposition 3), this is a novel finding. It extends (Gourinchas and Jeanne 2006; Coeurdacier, Ray, and Winant 2019), by highlighting how financial integration under imperfect competition affects a group of countries' joint welfare. This finding is relevant for unions of countries such the European Union, where a supra-national redistribution mechanism exists. 
A) Under a very small market size: $\mathrm{A}=20$
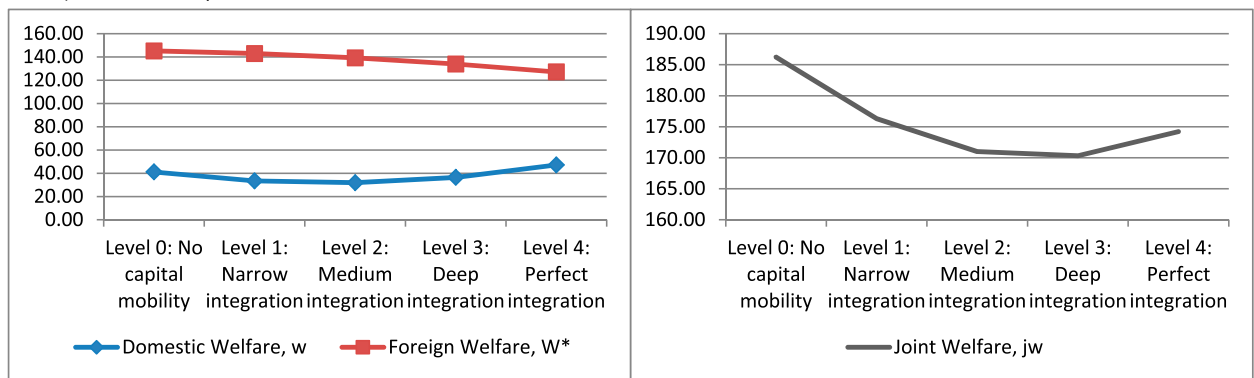

B) Under a small market size: $A=30$
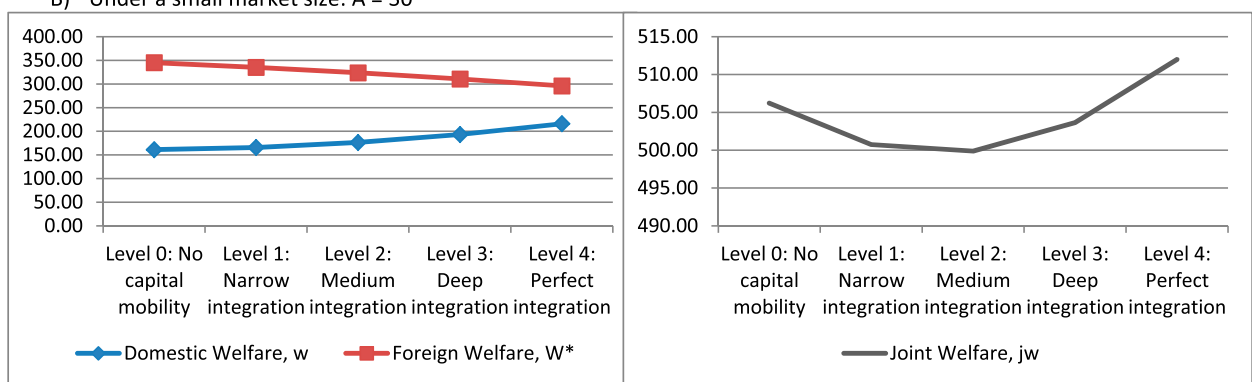

C) Under a moderate market size: $\mathrm{A}=40$
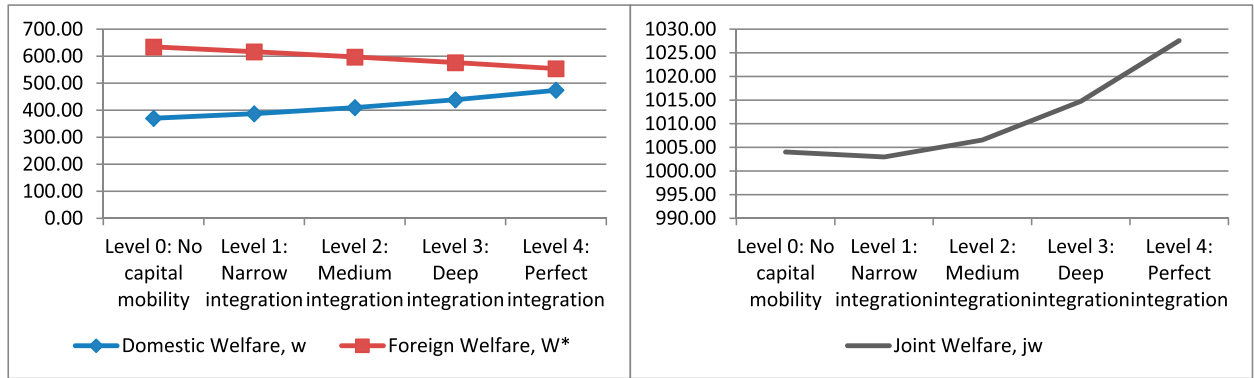

D) Under a large market size: $A=60$

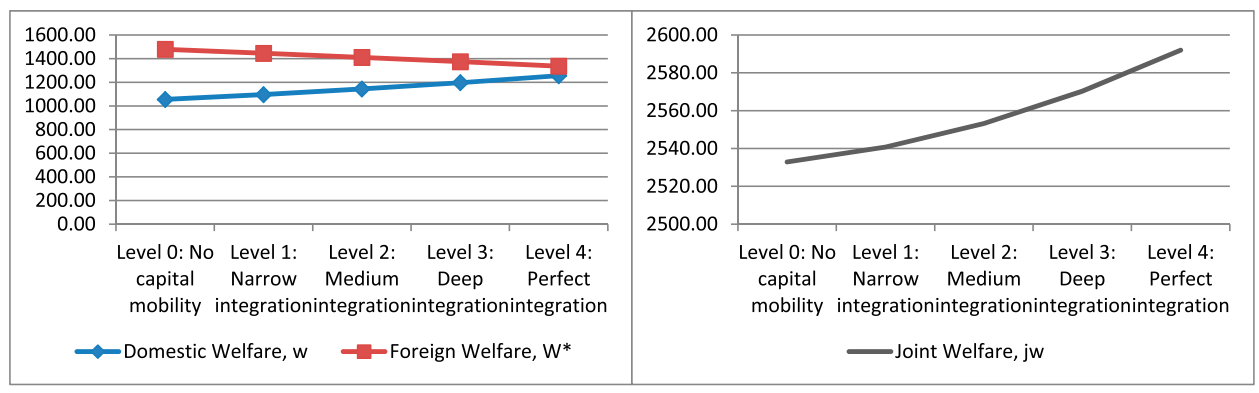

Figure 1. The welfare effects of capital-market integration when $A=B ;|-d R|>\left|d R^{*}\right|$.

Moving to panel $\mathrm{C}$ which uses a moderate market size $(A=40)$, Home once again is better off even from the first level of integration, but Foreign is worse off. Contrary to panel B, joint welfare requires only moderate integration level (Level 2) in order to improve. Panel D presents the results when this process occurs between two large countries $(A=60)$. In this case, Home is better off even from the initial level of integration, and Foreign is worse off as previously. The joint welfare is higher even from the initial level of the process (Level 1). Last, panel E yields similar results with panel D. ${ }^{24}$ The conclusions from Table 2 are illustrated in Figure 1 and are summarized in Proposition 4.2. 
Intuitively, the reduction in the average cost of capital due to financial integration, affects the two countries' joint welfare as follows. First, it reduces the average cost of production, which causes prices of goods to decrease. As a result, consumer surpluses in both countries increase, affecting positively their joint welfare. Second, it increases profits for Home' s firm and decreases that of Foreign's firm. For large enough market size, and or degree of financial integration, the positive effect on profits outweighs the negative one, contributing positively to their joint welfare.

For coherence and completeness purposes, we also run the same exercise, but for an extremely small market size (in terms of our F.O.C.), i.e. $A=16.5$. Only under this restricted scenario that includes (i) $|-d R|>\left|d R^{*}\right|$, (ii) market size very close to $A^{\mathrm{min}}$, and (iii) very narrow integration level, Foreign may achieve a welfare improvement from an increase in its cost of capital due to international capital outflows. The results for this scenario are presented in Table A1 and in Figure A1 in Appendix 2. According to it, when the economies move from 'No-mobility' to 'Narrow capital integration,' Foreign's welfare rises from 96.11 to 96.63.

Proposition 4.2: Assume two countries, Home with high capital cost and Foreign with low capital cost. International financial integration equalizes the cost of capital between the two countries. If the cost of capital under financial integration, $R^{c m}$, is lower than the average of the initial cost of capital without international capital flows, $\left(R+R^{*}\right) / 2$, then this capital integration process results in:

- an increase in Home's welfare for a sufficiently large market size and/or high level of integration,

- a decrease in Foreign's welfare, except for the restrictive case of an extremely small market along with a very limited level of integration,

- an increase in joint welfare only under a large-enough market size and/or a high level of capital integration.

This finding from our simulation study is in line with our theoretical ones in Propositions 3.1 and 3.3. Because the case we examine assumes that $|-d R|>\left|d R^{*}\right|$, this scenario also captures the specific case we analyze in the marginal analysis, where we assume a reduction in the cost of capital for the Home keeping $R^{*}$ unchanged, i.e. $|-d R|>0$ while $\left|d R^{*}\right|=0$.

Particularly, Figure 1 presents the integration process under four different market sizes. The total outcome is consistent with Propositions 3.1-4.1. The plot on the LHS for each pair shows the welfare level for each country during the financial integration process and as expected, it maps the welfare convergence for the two countries. The RHS plot in each pair shows how joint welfare responds to this international financial integration process. Clearly the market size, $A$, as well as the differences in the marginal cost of capital, $\left(R-R^{*}\right)$, affect joint welfare in the manner explained earlier.

In Table 3, we examine a case in which the international financial integration process decreases Home's cost of capital by less than it increases Foreign's cost of capital (i.e. $|-d R|<\left|d R^{*}\right|$ ). In this case, the equilibrium cost of capital under a perfect financial integration is higher than the average of the initial cost of capital in the two countries (e.g. the average cost of capital equals 8 at Level 4 compared to 7 at Level 0). Similar to all the previous scenarios, Home's welfare improves in a sufficiently large market size and/or high level of integration, but Foreign is worse off. Finally, under the current scenario, an international financial integration process reduces the joint welfare independently of market size, $A$ (see panels A-E of Table 3 ) ${ }^{25}$ Specifically, under our model's assumption of imperfect competition, linearity in cost, preferences and in the production technology, we show that when $0 \leq|-d R|<\left|d R^{*}\right|$, the average cost of capital in the integrated capital market is higher than in autarky. As a result, the international financial integration leads the two countries to a lower joint welfare. This finding from our simulation study is in line with our theoretical ones in Propositions 3.2 and 3.3.

Intuitively, in this case, the capital liberalization causes the average cost of production in the two countries to increase, and thus the price of goods in both countries increase, resulting in a decrease in consumer surpluses. The decrease in capital cost in Home causes profits to increase while the increase in capital cost in Foreign, causes Foreign profits to decrease. Since the reduction in cost in Home is smaller than the increase in Foreign, the increase in Home's profits is smaller than the decrease in Foreign' s profits, causing a reduction in total profits. Thus, in this case, capital liberalization reduces joint welfare since it reduces consumer surpluses in both countries and total profits. ${ }^{26}$. 
Proposition 4.3: Assume two countries, Home with high capital cost and Foreign with low capital cost. International financial integration equalizes the cost of capital between the two countries. If the cost of capital under financial integration process, $R^{\mathrm{cm}}$, is higher than the average of the initial cost of capital without international capital flows, $\left(R+R^{*}\right) / 2$, then this capital integration process results in:

- an increase in Home's welfare for a sufficiently large market size and/or high level of integration,

- a decrease in Foreign's welfare,

- a decrease in joint welfare.

Finally, we want to emphasize the following. In autarky, Foreign producers pay lower funding cost than producers in Home. That is, Foreign, by restricting capital outflow, indirectly subsidizes its producers. The liberalization of capital movements increases the cost of capital for Foreign producers and decreases that of Home ones, causing redistribution of profits from Foreign to Home producers. Since trade in goods is free, consumers in both countries pay the same price. The consumer surplus increases and consumers in both countries are better off if the prices of goods decrease. This happens if the cost of production decreases, which occurs if the cost of capital after liberalization is lower than the average of the initial cost of capital in the two countries. As we mention before (see Section 3.2),our results depend on the model's assumption of imperfect competition, on the total market size, on the initial cost of capital in the two countries, and on the assumption of linearity in cost, preferences, and the production technology. ${ }^{27}$

\section{Concluding remarks}

We build a simple two-country partial equilibrium model with international duopoly. We assume capital endowment heterogeneity, which implies different cost of capital for the two international rival firms in autarky. Within this framework, we allow for an increase in international capital flows between the two countries, which results in the convergence of their cost of capital, and we examine the effects of this convergence on the welfare of each country and on their joint welfare.

We start, with the marginal analysis, where we allow for a small change in the cost of capital for each country. This analysis shows that international capital liberalization cannot guarantee the improvement in each country's welfare and in their joint welfare. Specifically, we show, among other things, that (i) reducing the cost of capital of the high-cost country (Home) due to international capital liberalization between the two countries, increases its welfare if the market size is sufficiently large and/or the difference in the cost of capital is sufficiently small; and (ii) increasing capital cost of the low-cost country (Foreign) due to international capital outflows, decreases its welfare, except under a very restrictive scenario with an extremely small total market size associated with a very small difference in the cost of capital. Regarding the joint welfare, we find that (i) the convergence in the cost of capital increases the joint welfare of the two countries if the reduction in the high-cost country's cost of capital (Home) is associated with a sufficiently large market size and/or the differences in the initial costs of capital is not large; and (ii) the increase in the low-cost country's capital cost (Foreign) unambiguously decreases their joint welfare. Our results depend on the imperfect competition level in the product markets which creates profits to the two international rivals, on the total market size, and on the initial differences in the capital cost between the two countries.

In turn, we run a simulation study, where we allow for simultaneous changes in the cost of capital for the two countries due to an increase in the international capital flows between them. The results show that the only scenario in which the perfect international financial integration increases the two countries' joint welfare is when (a) the common cost of capital due to unrestricted international capital flows is lower than the average of the initial cost of capital in the two countries; and (b) the market size is sufficiently large. These conditions are more likely to be satisfied when the financial integration occurs between countries with a good enough level of economic, institutional, and financial development. The latter are identified by the relevant literature as factors that affect the final outcome of an international financial integration. Thus, the policymakers should take them into consideration before proceeding with international financial integration. Under these conditions, it is more likely that each unit of capital is used effectively, to generate synergies and thus economies of scales, that 
reduces the unit cost of production. By imposing criteria regarding the economic, institutional, and financial development of the economies that participate in the international financial integration process, increases the possibility for a capital cost reduction and thus for a joint welfare improvement. Such criteria could be, for example, the Eurozone criteria.

Moreover, we find that irrespective of the market size in the two countries, when the common cost of capital due to unrestricted international capital flows equals their average initial cost of capital, then their joint welfare unambiguously decreases with international capital liberalization. That is, unrestricted international capital flows that equalize the marginal cost of capital in the two countries leads to a welfare inferior outcome compared to the case of no capital mobility and unequal marginal cost of capital. Thus, the well-known result of Salant and Shaffer (1999) who showed, within an industry of one country, that the symmetric Cournot is a welfare inferior to the asymmetric one, carries over to our framework with an international duopoly, and international capital flows.

Our analysis shows that in the presence of an international duopoly, the international capital flows' liberalization that converges the capital cost among countries is not necessarily socially desirable in the sense that it does not always lead to a Pareto-improved outcome. These results add to the general debate concerning the use of capital restrictions between countries in order to avoid negative effects on their welfare.

Our findings have important policy implications. First, we emphasize that the degree of competition in the product market is an important factor that determines the welfare impact of the capital integration process. Second, the market size and the similarity of the capital costs in the two countries involved, play a crucial role not only for the effect on each country but also for their joint welfare. The above factors should be taken into consideration by the policymakers when they proceed with the capital market liberalization.

This work opens a window for future research. Since the impact of international financial integration on the countries' welfare level is a rather debated issue, the above theoretical findings could be tested empirically. This will further enhance our understanding regarding the relationship between international financial integration and countries' welfare.

\section{Notes}

1. These results motivated the relevant early 1990 and 2000 empirical literature (see Alesina, Grilli, and Milesi-Ferretti 1994).

2. See The Wall Street Journal of the 5 February 2016.

3. Salant and Shaffer (1999) reached the above conclusion, using a model with one industry in one country (not in an international duopoly), where the change in the marginal cost is due to intra country changes in the use of capital by domestic firms (not due to international capital flows).

4. In general, the inverse demand we obtain from the quasi-linear utility functions are of the form: $p(q)=A-b q$, where $b>0$.

5. Such an initial capital abundance heterogeneity could be the result of differences in financial development (see e.g. Mendoza, Quadrini, and Rios-Rull 2009).

6. When international capital flows are restricted, firms in each country get capital only from their local capital market. Thus, firms in Home get capital from the local capital market and pay higher price compared to firms in Foreign.

7. Our definition of the welfare measure follows a usual practice of the literature (e.g. Fanti, 2016; Stark et al., 2018; Bergin, 2018).

8. In the absence of international capital flows, the cost of capital may decrease due to other reasons such as an improvement in technology. In this case, $\phi=0$.

9. Note that we assume a simple production function, which is a one-to-one relationship between capital and output (i.e. $q(k)=k$, where $k$ denotes capital).

10. Using the F.O.C. country's production before capital mobility, $\alpha=\left(\hat{x}^{0}+\hat{y}^{0}\right)=\frac{2}{3}\left(A-2 R^{0}+R^{*}\right)$.

11. Because Home by assumption is the capital-importer country: $x+y>\alpha$.

12. The effect of a change in $R$ on NCP is given as follows: $N C P_{R}=\frac{2}{3}\left(A-4 R+R^{*}-3 \alpha\right) \gtreqless 0$. Its sign is ambiguous and depends on the market size, $A$, and the difference in the cost of capital, $\left(R-R^{*}\right)$, (see Appendix 2 for analytic calculations). Using $N C P_{R}$ we can show that the second partial derivative with respect to the Home's cost of capital, $R$, is negative: $N C P_{R R}<0$. Thus, as the capital-market integration proceeds toward the equalization of capital costs in the two countries, the high-cost country, Home, pays less for each further level of integration.

13. This finding is in the spirit of Mendoza, Quadrini, and Rios-Rull (2009) who find that domestic financial development may crucially affect the financial integration outcome.

14. This finding is also in line with (Coeurdacier, Ray, and Winant, 2019) who using a more complicated stochastic model show that market size is one of the factors that crucially affect the welfare gains of a single country due to international financial integration. 
15. The sign of the partial derivative of the net capital payments with respect to Foreign's cost of capital, $R^{*}$, is negative (i.e. revenue for Foreign) and thus it has a positive impact on the welfare of Foreign (capital exporter). Intuitively, when $R^{*}$ increases, the profit-maximizing output of the Foreign firm decreases, thus Home's firm output increases, which increases the use of capital and thus capital payments increase: $N C P_{R^{*}}^{*}=-\frac{2}{3} R<0$. Also, as we can see the partial derivative of $N C P_{R^{*}}^{*}$ with respect to the

Home cost of capital, $R$, yields: $N C P_{R^{*} R}=-\frac{2}{3}<0$ and because $R$ is lower due to capital mobility, the effect of an $R^{*}$ increase on net capital payments that Foreign receives is lower.

16. See Appendix 4 for more numerical examples.

17. These last two terms show the spillover effects from a decrease in Home's cost of capital on Foreign's welfare. That is, a decrease in Home's cost of capital causes an increase in the optimal Home output and leads to lower Foreign production and profits. Moreover, a decrease in Home's cost of capital, $R$, ceteris paribus leads to a higher Home total production $x+y$, lower price, and thus higher Foreign consumer surplus (i.e. $\left.\left(y+y^{*}\right)^{2} / 2\right)$ (see Appendix 4 for analytical calculations).

18. Valta (2012), in a slightly different content find that industry competitiveness affects the cost of capital for the participant firms.

19. From Equation (22) it is clear that in the special case, where $R=R^{*}$ and given the initial condition for interior solution (i.e. $\left.A>2 R-R^{*}\right)$, we find that $J W_{R}<0$.

20. In untabulated tests, we check the robustness of Proposition 3.3 under country size heterogeneity and for various levels of capital cost differences. All the equations with market size heterogeneity are available upon request.

21. An example of zero trade cost could be the intra E.U. free product mobility. We recognize the existence of fixed trade costs, but for simplicity we choose to ignore them since are considered small.

22. The simulations incorporate the relevant model's restrictions as they described by Equation (A2).

23. We also examine the restrictive scenario of an extremely small market size $(A=16.5)$ under three different scenarios: (i) $\mid-$ $d R|>| d R^{*} \mid$ (see Table A1 and Figure A1), (ii) $|-d R|=\left|d R^{*}\right|$ (see Table A2) and (iii) $|-d R|<\left|d R^{*}\right|$ (see Table A3). We find that Foreign for a small degree of capital-market integration is better off only under the first scenario. As we explain in Section 3, net capital payments drive this outcome.

24. Running the same exercise under market-size heterogeneity (i.e. $A \neq B$ ), we end up with exactly the same qualitative results. We do not report these results, however they are available upon request.

25. Once again, running the same exercise under market-size heterogeneity (i.e. $A \neq B$ ), we end up with exactly the same qualitative results. We do not report these results; however, they are available upon request.

26. A group of countries such as Mexico, Russia, Argentina, Thailand and South Korea with liberalized capital markets in $80^{\prime}$ and $90^{\prime}$ experienced severe financial crises, that hurt these countries' welfare. The empirical literature highlights a number of factors such as the level of economic, institutional and financial development, that may cause a negative outcome (see e.g. Chen and Quang, 2014)

27. In this paper, we use a partial equilibrium analysis. That is, we consider only the effect of changes in the prices of goods on consumer surplus and we ignore the effects of capital flows on asset returns and thus on incomes of capital owners. In more general models with capital owners and workers, capital flows increase incomes of capital owners and decrease wages in the capital exporting country, while they increase wages and decrease incomes of capital owners in the capital importing country. These changes in incomes affect welfare directly. For example, in a general equilibrium model with perfect competition and net capital payments, at constant goods prices, the international capital flows increase total income in each country. Within the framework of this paper, with imperfect competition (i.e. international duopoly) and flexible goods' prices, the effects of changes in income of factor owners on each country's welfare is generally ambiguous.

\section{Acknowledgments}

Previous versions of this paper were presented at the 13th Conference on Research on Economic Theory and Econometrics (CRETE), the 6th International Ioannina Meeting on Applied Economics and Finance (IMAEF), the University of Cyprus, and the Panteion University; and the authors are grateful to conference and seminars participants for their comments. The authors are especially grateful for comments and suggestions from the participants of the Doctoral School of International Institute of Public Finance (IIPF) at University of Oxford as well as comments and suggestions from Fabio Antoniou, Michael Devereux, Manthos Delis, Costas Hadjiyiannis, Panos Hatzipanayotou, Michael Keen, Christos Kotsogiannis, Theodore Mariolis, Raul Minetti, Pascalis Raimondos - Møller, Nikolaos Tsakiris, and Nikolaos Ziros.

\section{Disclosure statement}

No potential conflict of interest was reported by the author(s).

\section{ORCID}

Panagiotis Karavitis (D) http://orcid.org/0000-0002-6062-1197

Michael S. Michael (D) http://orcid.org/0000-0002-7642-1261 


\section{References}

Alesina, A., V. Grilli, and G. M. Milesi-Ferretti. 1994. “The Political Economy of Capital Controls.” In Capital Mobility: The Impact on Consumption, Investment and Growth, edited by L. Leiderman and A. Razin, 289-321. Cambridge: Cambridge University Press.

Arteta, C. O., B. Eichengreen, and C. Wyplosz. 2003. "When Does Capital Account Liberalization Help More than It Hurts?” In Economic Policy in the International Economy: Essays in Honor of Assaf Razin, edited by E. Helpman and E. Sadka 191-220. Cambridge: Cambridge University Press.

Bekaert, G., C. R. Harvey, and C. Lundblad. 2005. “Does Financial Liberalization Spur Growth?” Journal of Financial Economics 77: 3-55.

Bergin, J. 2018. "Patent Policy, Investment and Social Welfare.” International Journal of Industrial Organization 61: $439-458$.

Brander, J., and P. Krugman. 1983. “A 'Reciprocal Dumping' Model of International Trade.” Journal of International Economics 15: 313-321.

Chanda, A. 2005. “The Influence of Capital Controls on Long Run Growth: Where and How Much?” Journal of Development Economics 77: 441-466.

Chen, J., and T. Quang. 2014. “The Impact of International Financial Integration on Economic Growth: New Evidence on Threshold Effects.” Economic Modelling 42: 475-489.

Chinn, M., and H. Ito. 2005. "What Matters for Financial Development? Capital Controls, Institutions, and Interactions." Journal of Development Economics 81: 163-192.

Coeurdacier, N., H. Ray, and P. Winant. 2019. "Financial Integration and Growth in A Risky World." Journal of Monetary Economics 112: 1-21.

Colacito, R., and M. Croce. 2010. “The Short and Long Run Benefits of Financial Integration.” American Economic Review 100: 527-531.

Corneli, F. 2017. Medium and Long Term Implications of Financial Integration Without Financial Development. Bank of Italy (Working Paper) No. 1120.

De Nicolo, G., and L. Juvenal. 2014. "Financial Integration, Globalization, and Real Activity.” Journal of Financial Stability 10: 65-75.

Edison, H., M. W. Klein, L. A. Ricci, and T. M. Slok. 2004. "Capital Account Liberalization and Economic Performance: Survey and Synthesis." Journal of International Money and Finance 51: 220-256.

Edison, H., R. Levine, L. A. Ricci, and T. M. Slok. 2002a. "International Financial Integration and Economic Growth." Journal of International Money and Finance 21: 749-776.

Edwards, S. 2001. "Capital Mobility and Economic Performance: Are Emerging Economies Different." In The Worlds New Financial Landscape: Challenges for Economic Policy, edited by H. Siebert, 219-244. Berlin: Springer.

Fanti, L. 2016. "Social Welfare and Cross-Ownership in A Vertical Industry: When the Mode of Competition Matters for Antitrust Policy." Japan and the World Economy 37-38: 8-16.

Gourinchas, P. O., and O. Jeanne. 2006. “The Elusive Gains From International Financial Integration.” Review of Economic Studies 73: 715-741.

Grilli, V., and G. M. Milesi-Ferretti. 1995. “Economic Effects and Structural Determinants of Capital Controls.” IMF Staff Papers 42: 517-551.

Henry, P. B. 2007. “Capital Account Liberalization: Theory, Evidence, and Speculation.” Journal of Economic Literature 45: 887-935.

Klein, M. W. 2003. Capital Account Openness and the Varieties of Growth Experience. Unpublished Working Paper 9500, National Bureau of Economic Research, Cambridge, MA.

Klein, M. W., and G. Olivei. 2008. "Capital Account Liberalization, Financial Depth and Economic Growth.” Journal of International Money and Finance 27: 861-875.

Kose, M. A., E. Prasad, K. Rogoff, and S. J. Wei. 2009. “Financial Globalization: A Reappraisal.” IMF Staff Papers 56: 8-62.

Kraay, A. 1998. In Search of the Macroeconomic Effects of Capital Account Liberalizations. Unpublished working paper, World Bank, Washington, DC.

Mendoza, E., V. Quadrini, and J. Rios-Rull. 2009. “Financial Integration, Financial Development, and Global Imbalances.” Journal of Political Economy 117: 371-416.

Quinn, D. 1997. “The Correlates of Changes in International Financial Regulation.” American Political Science Review 91: 531-551.

Quinn, D., and A. M. Toyoda. 2003. Does Capital Account Liberalization Lead to Economic Growth? An Empirical Investigation. Unpublished working paper, Georgetown University, Washington, DC.

Rodrik, D. 1998. "Who Needs Capital Account Convertibility?” Princeton Essays in International Finance207: 1-10.

Salant, S., and G. Shaffer. 1999. “Unequal Treatment of Identical Agents in Cournot Equilibrium.” American Economic Review 89: 585-604.

Stark, O., E. Zawojska, W. Kohler, and K. Szczgielski. 2018. “An Adverse Social Welfare Effect of A Doubly Gainful Trade.” Journal of Development Economics 135: 77-84.

Valta, P. 2012. “Competition and The Cost of Debt." Journal of Financial Economics 105: 661-682. 


\section{Appendices}

\section{Appendix 1. Marginal analysis}

\section{A.1 First-order conditions}

Solving the profit maximization problem for the firms (see Equations (7) and (8)), we can obtain the equilibrium outputs as follows:

$$
\left\{\begin{array}{l}
\hat{x}=\frac{1}{3}\left(A-2 R+R^{*}\right), \hat{y}=\frac{1}{3}\left(A-2 R+R^{*}\right), \\
\hat{x}^{*}=\frac{1}{3}\left(A+R-2 R^{*}\right), \hat{y}^{*}=\frac{1}{3}\left(A+R-2 R^{*}\right) .
\end{array}\right\}
$$

Using the conditions (A1), we derive the conditions required for an interior solution as follows:

$$
\left(A-2 R+R^{*}\right)>0 ; \quad\left(A+R-2 R^{*}\right)>0 .
$$

According to Equation (A2), it is required that $A>2 R-R^{*}$ and $A>2 R^{*}-R$. However, since $R>R^{*}$, what is actually required is that $A>2 R-R^{*}$.

\section{A.2 The effect on Home's welfare}

Differentiating Home welfare (i.e. Equation (5)) with respect to its own marginal cost yields:

$$
\frac{\partial W}{\partial R}=\frac{\partial \Pi}{\partial R}+\frac{\partial C S}{\partial R}-\frac{\partial N C P}{\partial R} .
$$

Substitute the equilibrium outputs from Equation (A1) and calculating each partial derivative on the RHS, we obtain:

$$
\begin{aligned}
& \frac{\partial \Pi}{\partial R}=\left(A-x-x^{*}\right) \frac{\partial x}{\partial R}-x\left(\frac{\partial x}{\partial R}+\frac{\partial x^{*}}{\partial R}\right)+\left(A-y-y^{*}\right) \frac{\partial y}{\partial R} \\
&-y\left(\frac{\partial y}{\partial R}+\frac{\partial y^{*}}{\partial R}\right)-R\left(\frac{\partial x}{\partial R}+\frac{\partial y}{\partial R}\right)-(x+y) \Rightarrow \\
& \frac{\partial \Pi}{\partial R}=\left(A-2 x-x^{*}-R\right) \frac{\partial x}{\partial R}-\left(A-2 y-y^{*}-R\right) \frac{\partial y}{\partial R} \\
&-x \frac{\partial x^{*}}{\partial R}-y \frac{\partial y^{*}}{\partial R}-(x+y) \Rightarrow \\
& \frac{\partial \Pi}{\partial R}=-\frac{8}{9}\left(A-2 R+R^{*}\right)<0 . \\
& \frac{\partial C S}{\partial R}=\left(x+x^{*}\right)\left(\frac{\partial x}{\partial R}+\frac{\partial x^{*}}{\partial R}\right) \Rightarrow \\
& \frac{\partial C S}{\partial R}=-\frac{1}{9}\left(2 A-R-R^{*}\right)<0 . \\
& \frac{\partial N C P}{\partial R}=(x+y-\alpha)+R\left(\frac{\partial x}{\partial R}+\frac{\partial x^{*}}{\partial R}\right) \Rightarrow \\
& 2 \frac{2}{3}\left(A-4 R+R^{*}\right)-\alpha \gtreqless 0 .
\end{aligned}
$$

Finally, we add Equations (A3)-(A5) to obtain the total effect of a decrease in Home's cost of capital on its welfare as shown in Equation (14).

\section{A.3 The effect on Foreign's welfare}

Differentiating Foreign welfare (i.e. Equation (6)) with respect to its own marginal cost, we obtain:

$$
\frac{\partial W^{*}}{\partial R^{*}}=\frac{\partial \Pi^{*}}{\partial R^{*}}+\frac{\partial C S^{*}}{\partial R^{*}}+\frac{\partial N C P}{\partial R^{*}} .
$$


Substituting the equilibrium outputs from Equation (A1) and calculating each partial derivative on the RHS, we obtain:

$$
\begin{aligned}
& \frac{\partial \Pi^{*}}{\partial R^{*}}=\left(A-x-x^{*}\right) \frac{\partial x^{*}}{\partial R^{*}}-x^{*}\left(\frac{\partial x}{\partial R^{*}}+\frac{\partial x^{*}}{\partial R^{*}}\right)+\left(A-y-y^{*}\right) \frac{\partial y^{*}}{\partial R^{*}} \\
&-y^{*}\left(\frac{\partial y}{\partial R^{*}}+\frac{\partial y^{*}}{\partial R^{*}}\right)-R^{*}\left(\frac{\partial x^{*}}{\partial R^{*}}+\frac{\partial y^{*}}{\partial R^{*}}\right)-\left(x^{*}+y^{*}\right) \Rightarrow \\
& \frac{\partial \Pi^{*}}{\partial R^{*}}=\left(A-x-2 x^{*}-R^{*}\right) \frac{\partial x^{*}}{\partial R^{*}}-\left(A-y-2 y^{*}-R^{*}\right) \frac{\partial y^{*}}{\partial R^{*}}-x^{*} \\
& \frac{\partial x}{\partial R^{*}}-y^{*} \frac{\partial y}{\partial R^{*}}-\left(x^{*}+y^{*}\right) \Rightarrow-\frac{8}{9}\left(A+R-2 R^{*}\right)<0 . \\
& \frac{\partial C S^{*}}{\partial R^{*}}=\left(y+y^{*}\right)\left(\frac{\partial y}{\partial R^{*}}+\frac{\partial y^{*}}{\partial R^{*}}\right) \Rightarrow \\
& \frac{\partial C S^{*}}{\partial R^{*}}=-\frac{1}{9}\left(2 A-R-R^{*}\right)<0 . \\
& \frac{\partial N C P}{\partial R^{*}}=R\left(\frac{\partial x}{\partial R^{*}}+\frac{\partial y}{\partial R^{*}}\right) \Rightarrow \\
& \frac{\partial R^{*}}{3}=\frac{2}{3} R<0 .
\end{aligned}
$$

Finally, we add Equations (A6) and (A8) to obtain the total effect of an increase in Foreign's cost of capital on its welfare as we show in Equation (18).

\section{A.4 Effects on Foreign's welfare: a numerical example}

We present below how an increase of Foreign's cost of capital, $R^{*}$, affects its welfare, using the restrictions of the F.O.C. for an interior solution (i.e. $A-2 R+R^{*}>0$ ) as well as Equations (18)-(20) for two different scenarios: (i) $A \in\left(A^{\text {min }}, A_{I}^{*}\right)$ (i.e. a relatively small market size), and (ii) $A>A_{I}^{*}$ (i.e. a relatively large market size).

Example A.1: Cost of capital for Home and Foreign: $\left(R=150, R^{*}=130\right) \Rightarrow \frac{R}{R^{*}}=\frac{150}{130}<\frac{27}{21}$.

So, using Equation (20): $A^{\text {min }}<A_{I}^{*}$.

Using the F.O.C.: $A^{\mathrm{min}}=2 R-R^{*}>0 \Rightarrow A^{\mathrm{min}}=2(150)-130 \Rightarrow A^{\mathrm{min}}=170$.

Using Equation (18): $W_{R^{*}}^{*}>0 \Rightarrow A<\frac{-R+17 R^{*}}{10} \Rightarrow A<\frac{-150+17(130)}{10} \Rightarrow A<206$ and thus $A_{I}^{*}=206$.

So, for: $A \in\left(A^{\min }, A_{I}^{*}\right) \Rightarrow A \in(170,206), W_{R^{*}}^{*}>0$.

Using Equation (18):

Scenario 1: $A=200 \Rightarrow W_{R^{*}}^{*}=-\frac{1}{9}(10(200)+150-17(130))=-\frac{1}{9}(-60) \Rightarrow W_{R^{*}}^{*}=\frac{60}{9}>0$.

Scenario 2: $A=207 \Rightarrow W_{R^{*}}^{*}=-\frac{1}{9}(10(207)+150-17(130))=-\frac{1}{9}(10) \Rightarrow W_{R^{*}}^{*}=-\frac{10}{9}<0$.

Example A.2: Cost of capital for Home and Foreign: $\left(R=160, R^{*}=120\right) \Rightarrow \frac{R}{R^{*}}=\frac{160}{120}>\frac{27}{21}$.

So, using Equation (20): $A^{\mathrm{min}}>A_{I}^{*}$.

Using the F.O.C.: $A^{\mathrm{min}}=2 R-R^{*}>0 \Rightarrow A^{\mathrm{min}}=2(160)-120 \Rightarrow A^{\mathrm{min}}=200$.

Using Equation (18): $W_{R^{*}}^{*}>0 \Rightarrow A<\frac{-R+17 R^{*}}{10} \Rightarrow A<\frac{-160+17(120)}{10} \Rightarrow A<188$ and thus $A_{I}^{*}=188$.

So, for $\left(\boldsymbol{R}=160, \boldsymbol{R}^{*}=120\right): A^{\mathrm{min}}>A_{I}^{*}$, and thus there is no scenario where $W_{R^{*}}^{*}>0$.

\section{A.5 The effects on joint welfare}

Differentiating joint welfare (i.e. Equation (21)) with respect to Home's cost of capital, $R$, gives:

$$
\frac{\partial J W}{\partial R}=\frac{\partial W}{\partial R}+\frac{\partial W^{*}}{\partial R} .
$$


The first term on the RHS is given by Equation (14). Using Equations (6), (10) and (8), and the equilibrium output from (A1), the effect of a change in Home's cost of capital on Foreign's welfare is given as follows:

$$
\begin{gathered}
\frac{\partial \Pi^{*}}{\partial R}=\left(A-x-x^{*}\right) \frac{\partial x^{*}}{\partial R}-x^{*}\left(\frac{\partial x}{\partial R}+\frac{\partial x^{*}}{\partial R}\right)+\left(A-y-y^{*}\right) \frac{\partial y^{*}}{\partial R} \\
-y^{*}\left(\frac{\partial y}{\partial R}+\frac{\partial y^{*}}{\partial R}\right)-R^{*}\left(\frac{\partial x^{*}}{\partial R}+\frac{\partial y^{*}}{\partial R}\right) \Rightarrow \\
\frac{\partial \Pi^{*}}{\partial R}=\left(A-x-2 x^{*}-R\right) \frac{\partial x^{*}}{\partial R}-\left(A-y-2 y^{*}-R^{*}\right) \frac{\partial y^{*}}{\partial R}-x^{*} \frac{\partial x}{\partial R}-y^{*} \frac{\partial y}{\partial R} \Rightarrow \\
\frac{\partial \Pi^{*}}{\partial R}=\frac{4}{9}\left(A+R-2 R^{*}\right)>0 . \\
\frac{\partial C S^{*}}{\partial R}=\left(y+y^{*}\right)\left(\frac{\partial y}{\partial R}+\frac{\partial y^{*}}{\partial R}\right) \Rightarrow \\
\frac{\partial C S^{*}}{\partial R}=-\frac{1}{9}\left(2 A-R-R^{*}\right)<0 \\
\frac{\partial N C P^{*}}{\partial R}=-\frac{\partial N C P}{\partial R}=-(x+y-\alpha)-R\left(\frac{\partial x}{\partial R}+\frac{\partial y}{\partial R}\right) \Rightarrow \\
\frac{2}{3}\left(A-4 R+R^{*}\right)+\alpha \gtreqless 0 .
\end{gathered}
$$

Finally, we add Equations (14) and (A9)-(A11) to determine how an increase in Home's cost of capital affects Foreign's welfare as shown in Equation (22). Similarly, the effect of a change in Foreign's cost of capital on the JW is:

$$
\frac{\partial J W}{\partial R^{*}}=\frac{\partial W^{*}}{\partial R^{*}}+\frac{\partial W}{\partial R^{*}} .
$$

The first term on the RHS is given by Equation (18). Using the equilibrium output from (A1) and Equations (6), (10), and (8), the effect of a change in Foreign's cost of capital on Home's welfare, is given by:

$$
\begin{gathered}
\frac{\partial \Pi}{\partial R^{*}}=\left(A-x-x^{*}\right) \frac{\partial x}{\partial R^{*}}-x\left(\frac{\partial x}{\partial R^{*}}+\frac{\partial x^{*}}{\partial R^{*}}\right)+\left(A-y-y^{*}\right) \frac{\partial y}{\partial R^{*}} \\
-y\left(\frac{\partial y}{\partial R^{*}}+\frac{\partial y^{*}}{\partial R^{*}}\right)-R\left(\frac{\partial x}{\partial R^{*}}+\frac{\partial y}{\partial R^{*}}\right) \Rightarrow \\
\frac{\partial \Pi}{\partial R^{*}}=\left(A-2 x-x^{*}-R\right) \frac{\partial x}{\partial R^{*}}-\left(A-2 y-y^{*}-R^{*}\right) \frac{\partial y}{\partial R^{*}}-x \frac{\partial x^{*}}{\partial R^{*}}-y \frac{\partial y^{*}}{\partial R^{*}} \Rightarrow \\
\frac{\partial \Pi}{\partial R^{*}}=\frac{4}{9}\left(A-2 R+R^{*}\right)>0 . \\
\frac{\partial C S}{\partial R^{*}}=\left(x+x^{*}\right)\left(\frac{\partial x}{\partial R^{*}}+\frac{\partial x^{*}}{\partial R^{*}}\right) \Rightarrow \\
\frac{\partial C S}{\partial R^{*}}=-\frac{1}{9}\left(2 A-R-R^{*}\right)<0 . \\
\frac{\partial N C P}{\partial R^{*}}=R\left(\frac{\partial x}{\partial R^{*}}+\frac{\partial y}{\partial R^{*}}\right) \Rightarrow \\
\frac{\partial N C P}{\partial R^{*}}=\frac{2}{3} R>0 .
\end{gathered}
$$

Finally, we add Equations (18) and (A12)-(A14) to obtain the total effect of an increase in Foreign's cost of capital on Home's welfare as shown by Equation (23).

\section{Appendix 2. Simulation analysis for Foreign}

In this appendix, we examine the conditions under which international financial integration improves the welfare level of the initially low-capital-cost country. According to the results of our simulations (see Proposition 4.2) for (i) a sufficiently small market size $A$, associated with (ii) a narrow capital-market integration and only for the case where (iii) the average marginal cost falls due to capitalmarket integration, the whole process could benefit the low-cost (Foreign) country. To get this result, we utilize an extremely small 

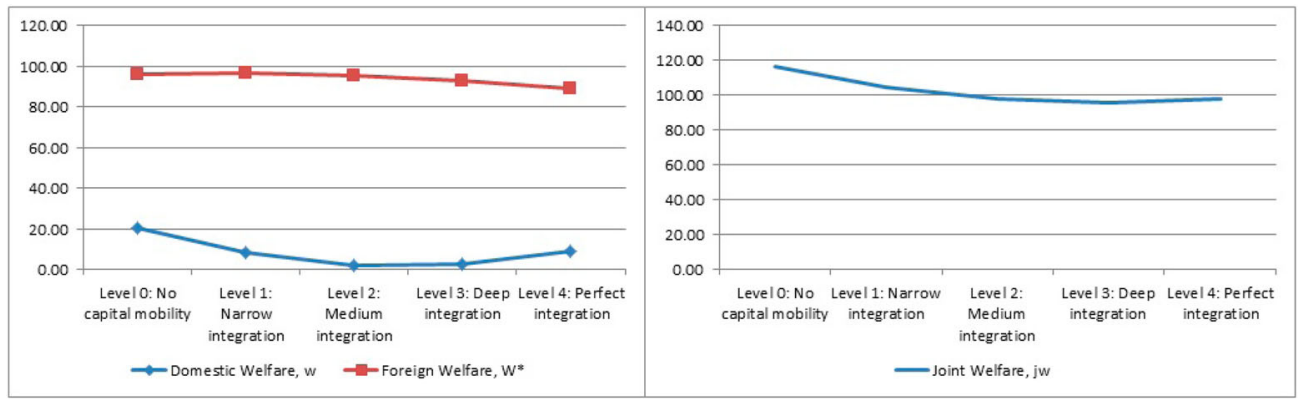

Figure A1. The welfare effects of international financial integration under an extremely small market size.

Table A1. The welfare effects of international financial integration: similar market size $(A=B)$ and $|-d R|>\left|d R^{*}\right|$.

\begin{tabular}{|c|c|c|c|c|c|}
\hline \multicolumn{6}{|c|}{ Extremely small market size: $A=16.5 ; \alpha=0.33$} \\
\hline $\begin{array}{l}\text { Level of international } \\
\text { financial integration }\end{array}$ & $\begin{array}{l}\text { Home's cost of } \\
\text { capital, } R\end{array}$ & $\begin{array}{l}\text { Foreign's cost } \\
\text { of capital, } R^{*}\end{array}$ & $\begin{array}{c}\text { Home } \\
\text { Welfare, } W\end{array}$ & $\begin{array}{c}\text { Foreign } \\
\text { Welfare, } W^{*}\end{array}$ & $\begin{array}{c}\text { Joint } \\
\text { Welfare, } J W\end{array}$ \\
\hline Level 0: No capital flows & 10.00 & 4.00 & 20.11 & 96.11 & 116.22 \\
\hline Level 1: Narrow financial integration & 9.00 & 4.50 & 8.13 & 96.63 & 104.75 \\
\hline Level 2: Moderate financial integration & 8.00 & 5.00 & 2.28 & 95.61 & 97.89 \\
\hline Level 3: Deep financial integration & 7.00 & 5.50 & 2.57 & 93.07 & 95.64 \\
\hline Level 4: Perfect financial integration & 6.00 & 6.00 & 9.00 & 89.00 & 98.00 \\
\hline
\end{tabular}

Table A2. The welfare effects of international financial integration: similar market size $(A=B)$ and $|-d R|=\left|d R^{*}\right|$.

\begin{tabular}{|c|c|c|c|c|c|}
\hline \multicolumn{6}{|c|}{ Extremely small market size: $A=16.5 ; \alpha=0.33$} \\
\hline $\begin{array}{l}\text { Level of international } \\
\text { financial integration }\end{array}$ & $\begin{array}{l}\text { Home's cost of } \\
\text { capital, } R\end{array}$ & $\begin{array}{l}\text { Foreign's cost } \\
\text { of capital, } R^{*}\end{array}$ & $\begin{array}{c}\text { Home } \\
\text { Welfare, } W\end{array}$ & $\begin{array}{c}\text { Foreign } \\
\text { Welfare, } W^{*}\end{array}$ & $\begin{array}{c}\text { Joint } \\
\text { Welfare, JW }\end{array}$ \\
\hline Level 0: No capital flows & 10.00 & 4.00 & 20.11 & 96.11 & 116.22 \\
\hline Level 1: Narrow financial integration & 9.00 & 5.00 & 4.78 & 91.44 & 96.22 \\
\hline Level 2: Deep financial integration & 8.00 & 6.00 & -2.56 & 86.78 & 84.22 \\
\hline Level 3: Perfect financial integration & 7.00 & 7.00 & -1.89 & 82.11 & 80.22 \\
\hline
\end{tabular}

Table A3. The welfare effects of international financial integration: similar market size $(A=B)$ and $|-d R|<\left|d R^{*}\right|$.

\begin{tabular}{lccccc}
\hline & \multicolumn{4}{c}{ Extremely small market size: $A=16.5 ; \alpha=0.33$} & \\
\hline $\begin{array}{l}\text { Level of international } \\
\text { financial integration }\end{array}$ & $\begin{array}{c}\text { Home's cost of } \\
\text { capital, } R\end{array}$ & $\begin{array}{c}\text { Foreign's cost } \\
\text { of capital, } R^{*}\end{array}$ & $\begin{array}{c}\text { Home } \\
\text { Welfare, } W\end{array}$ & $\begin{array}{c}\text { Foreign } \\
\text { Welfare, } W^{*}\end{array}$ & $\begin{array}{c}\text { Joint } \\
\text { Welfare, } J W\end{array}$ \\
\hline Level 0: No capital flows & 10.00 & 4.00 & 20.11 & 96.11 & 116.22 \\
Level 1: Narrow financial integration & 9.00 & 5.00 & 7.74 & 88.57 & 96.31 \\
Level 2: Deep financial integration & 8.00 & 6.00 & -1.50 & 82.50 & 81.00 \\
Level 3: Perfect financial integration & 7.00 & 7.00 & -7.60 & 77.90 & 70.31 \\
\hline
\end{tabular}

market size $(A=16.5)$, which is slightly higher than the minimum required by our model for an interior solution (i.e. $(A=16))$. The outcome of this exercise is shown in Table A1 and graphically in Figure 3.

The above three conditions must be satisfied in order for Foreign to improve its welfare through capital-market integration. To enhance the clarity of our argument, we also provide exactly the same scenario with the previous case but for the cases where (i) $\mid-$ $d R|=| d R^{*} \mid$ (i.e. unchanged average marginal cost after the capital-market integration) and (ii) $|-d R|<\left|d R^{*}\right|$ (i.e. higher average marginal cost after the capital-market integration). To this end, once again we utilize an extremely small market size $(A=16.5)$, which is slightly higher than the minimum required by our model for an interior solution (i.e. $A=16$ ). The outcome of this exercise is shown in Tables A2 and A3. 
Table A4. The welfare effects of international financial integration: different market size $(A \leq B)$ and $|-d R|=\left|d R^{*}\right|$.

\begin{tabular}{|c|c|c|c|c|c|}
\hline $\begin{array}{l}\text { Level of international } \\
\text { financial integration }\end{array}$ & $\begin{array}{l}\text { Home's cost of } \\
\text { capital, } R\end{array}$ & $\begin{array}{c}\text { Foreign's cost } \\
\text { of capital, } R^{*}\end{array}$ & $\begin{array}{c}\text { Home } \\
\text { Welfare, } W\end{array}$ & $\begin{array}{c}\text { Foreign } \\
\text { Welfare, } W^{*}\end{array}$ & $\begin{array}{c}\text { Joint } \\
\text { Welfare, JW }\end{array}$ \\
\hline \multicolumn{6}{|c|}{ Panel A: very small market size: $A=20, B=20 ; \alpha=2.67$} \\
\hline Level 0: No capital flows & 10.00 & 4.00 & 41.11 & 145.11 & 186.22 \\
\hline Level 1: Narrow financial integration & 9.00 & 5.00 & 30.44 & 135.78 & 166.22 \\
\hline Level 2: Deep financial integration & 8.00 & 6.00 & 27.78 & 126.44 & 154.22 \\
\hline Level 3: Perfect financial integration & 7.00 & 7.00 & 33.11 & 117.11 & 150.22 \\
\hline \multicolumn{6}{|c|}{ Panel B: small market size: $A=20, B=30 ; \alpha=9.33$} \\
\hline Level 0: No capital flows & 10.00 & 4.00 & 103.33 & 491.78 & 595.11 \\
\hline Level 1: Narrow financial integration & 9.00 & 5.00 & 106.00 & 469.11 & 575.11 \\
\hline Level 2: Deep financial integration & 8.00 & 6.00 & 116.67 & 446.44 & 563.11 \\
\hline Level 3: Perfect financial integration & 7.00 & 7.00 & 135.33 & 423.78 & 559.11 \\
\hline \multicolumn{6}{|c|}{ Panel C: moderate market size: $A=20, B=40 ; \alpha=16$} \\
\hline Level 0: No capital flows & 10.00 & 4.00 & 254.44 & 1105.11 & 1359.56 \\
\hline Level 1: Narrow financial integration & 9.00 & 5.00 & 270.44 & 1069.11 & 1339.56 \\
\hline Level 2: Deep financial integration & 8.00 & 6.00 & 294.44 & 1033.11 & 1327.56 \\
\hline Level 3: Perfect financial integration & 7.00 & 7.00 & 326.44 & 997.11 & 1323.56 \\
\hline \multicolumn{6}{|c|}{ Panel D: Large market size: $A=20, B=60 ; \alpha=29.33$} \\
\hline Level 0: No capital flows & 10.00 & 4.00 & 823.33 & 3131.78 & 3955.11 \\
\hline Level 1: Narrow financial integration & 9.00 & 5.00 & 866.00 & 3069.11 & 3935.11 \\
\hline Level 2: Deep financial integration & 8.00 & 6.00 & 916.67 & 3006.44 & 3923.11 \\
\hline Level 3: Perfect financial integration & 7.00 & 7.00 & 975.33 & 2943.78 & 3919.11 \\
\hline \multicolumn{6}{|c|}{ Panel E: very large market size: $A=20, B=80 ; \alpha=42.67$} \\
\hline Level 0: No capital flows & 10.00 & 4.00 & 1747.78 & 6225.11 & 7972.89 \\
\hline Level 1: Narrow financial integration & 9.00 & 5.00 & 1817.11 & 6135.78 & 7952.89 \\
\hline Level 2: Deep financial integration & 8.00 & 6.00 & 1894.44 & 6046.44 & 7940.89 \\
\hline Level 3: Perfect financial integration & 7.00 & 7.00 & 1979.78 & 5957.11 & 7936.89 \\
\hline
\end{tabular}

Table A5. The welfare effects of international financial integration: different market size $(A \geq B)$ and $|-d R|=\left|d R^{*}\right|$.

\begin{tabular}{|c|c|c|c|c|c|}
\hline $\begin{array}{l}\text { Level of international } \\
\text { financial integration }\end{array}$ & $\begin{array}{l}\text { Home's cost of } \\
\text { capital, } R\end{array}$ & $\begin{array}{l}\text { Foreign's cost } \\
\text { of capital, } R^{*}\end{array}$ & $\begin{array}{c}\text { Home } \\
\text { Welfare, } W\end{array}$ & $\begin{array}{c}\text { Foreign } \\
\text { Welfare, } W^{*}\end{array}$ & $\begin{array}{c}\text { Joint } \\
\text { Welfare, } J W\end{array}$ \\
\hline \multicolumn{6}{|c|}{ Panel A: very small market size: $A=20, B=20 ; \alpha=2.67$} \\
\hline Level 0: No capital flows & 10.00 & 4.00 & 41.11 & 145.11 & 186.22 \\
\hline Level 1: Narrow financial integration & 9.00 & 5.00 & 30.44 & 135.78 & 166.22 \\
\hline Level 2: Deep financial integration & 8.00 & 6.00 & 27.78 & 126.44 & 154.22 \\
\hline Level 3: Perfect financial integration & 7.00 & 7.00 & 33.11 & 117.11 & 150.22 \\
\hline \multicolumn{6}{|c|}{ Panel B: small market size: $A=40, B=20 ; \alpha=9.33$} \\
\hline Level 0: No capital flows & 10.00 & 4.00 & 307.78 & 287.33 & 595.11 \\
\hline Level 1: Narrow financial integration & 9.00 & 5.00 & 310.44 & 264.67 & 575.11 \\
\hline Level 2: Deep financial integration & 8.00 & 6.00 & 321.11 & 242.00 & 563.11 \\
\hline Level 3: Perfect financial integration & 7.00 & 7.00 & 339.78 & 219.33 & 559.11 \\
\hline \multicolumn{6}{|c|}{ Panel C: moderate market size: $A=60, B=20 ; \alpha=16$} \\
\hline Level 0: No capital flows & 10.00 & 4.00 & 841.11 & 518.44 & 1359.56 \\
\hline Level 1: Narrow financial integration & 9.00 & 5.00 & 857.11 & 482.44 & 1339.56 \\
\hline Level 2: Deep financial integration & 8.00 & 6.00 & 881.11 & 446.44 & 1327.56 \\
\hline Level 3: Perfect financial integration & 7.00 & 7.00 & 913.11 & 410.44 & 1323.56 \\
\hline \multicolumn{6}{|c|}{ Panel D: large market size: $A=100, B=20 ; \alpha=29.33$} \\
\hline Level 0: No capital flows & 10.00 & 4.00 & 2707.78 & 1247.33 & 3955.11 \\
\hline Level 1: Narrow financial integration & 9.00 & 5.00 & 2750.44 & 1184.67 & 3935.11 \\
\hline Level 2: Deep financial integration & 8.00 & 6.00 & 2801.11 & 1122.00 & 3923.11 \\
\hline Level 3: Perfect financial integration & 7.00 & 7.00 & 2859.78 & 1059.33 & 3919.11 \\
\hline \multicolumn{6}{|c|}{ Panel E: very large market size: $A=140, B=20 ; \alpha=42.67$} \\
\hline Level 0: No capital flows & 10.00 & 4.00 & 5641.11 & 2331.78 & 7972.89 \\
\hline Level 1: Narrow financial integration & 9.00 & 5.00 & 5710.44 & 2242.44 & 7952.89 \\
\hline Level 2: Deep financial integration & 8.00 & 6.00 & 5787.78 & 2153.11 & 7940.89 \\
\hline Level 3: Perfect financial integration & 7.00 & 7.00 & 5873.11 & 2063.78 & 7936.89 \\
\hline
\end{tabular}

